\title{
Dnmt3a is downregulated by Stat5a and mediates G0/G1 arrest by suppressing the miR-17-5p/Cdkn1a axis in Jak2 ${ }^{\mathrm{V} 617 \mathrm{~F}}$ cells
}

Jie Zhou ${ }^{1,2+}$, Cheng Guo ${ }^{1,2+}$, Hao Wu ${ }^{1,3}$, Bing Li $i^{1,3}$, Li-Li Zhou ${ }^{1,3}$, Ai-Bin Liang ${ }^{1,3^{*}}$ and Jian-Fei Fu ${ }^{1,3^{*}}$

\begin{abstract}
Background: Despite of the frequently reported Dnmt3a abormality in classical myeloproliferative neoplasms (cMPNs) patients, few research explores how the Dnmt3a is regulated by Jak2 ${ }^{\mathrm{V} 617 \mathrm{~F}}$ mutation. In this study, we have investigated how the Dnmt3a is regulated by Jak2 ${ }^{\mathrm{V} 617 \mathrm{~F}}$ mutation and its effects on downstream signaling pathways in CMPNs.
\end{abstract}

Methods: Specimens of Jak2 $2^{\mathrm{V} 617 \mathrm{~F}}$ positive cMPN patients and normal controls were collected. Murine BaF3 cell line was used to construct cell models. Dual-Glo luciferase assays and chromatin immunoprecipitation (ChIP)-qPCR were performed to detect the impact of Stat5a on transcription activity of Dnmt3a. Soft agar colony formation assay and cell counting assay were performed to detect cell proliferation. BrdU staining and flow cytometry were used to investigate cell cycle distribution. Western blotting and quantitative reverse-transcription PCR (qPCR) were performed to detect the expression levels of genes.

Results: Firstly, the results of western blotting and GPCR revealed that compared with the control samples, Dnmt3a is downregulated in Jak2 ${ }^{\mathrm{V} 617 \mathrm{~F}}$ positive samples. Then we explored the mechanism behind it and found that Dnmt3a is a downstream target of Stat5a, the transcription and translation of Dnmt3a is suppressed by the binding of aberrantly activated Stat5a with Dnmt3a promoter in Jak ${ }^{\mathrm{V} 617 \mathrm{~F}}$ positive samples. We further revealed the region approximately $800 \mathrm{bp}$ upstream of the first exon of the Dnmt3a promoter, which includes a gamma-activated sequence (GAS) motif of Stat5a, is the specific site that Stat5a binds to. Soft agar colony formation assay, cell counting assay, and BrdU staining and flow cytometry assay found that Dnmt3a in Jak2 ${ }^{\mathrm{V} 617 \mathrm{~F}}-\mathrm{BaF} 3$ cells significantly affected the cell proliferation capacity and cell cycle distribution by suppressing Cdkn1a via miR-17-5p/Cdkn1a axis and mediated G0/G1 arrest.

Conclusions: Transcription and translation of Dnmt3a is downregulated by the binding of Stat5a with Dnmt3a promoter in Jak2 ${ }^{\mathrm{V} 617 \mathrm{~F}}$ cells. The GAS motif at promoter of Dnmt3a is the exact site where the Stat5a binds to. Dnmt3a conducted GO/G1 arrest through regulating miR-17-5p/Cdkn1a axis. The axis of Stat5a/Dnmt3a/miR-17-5p/Cdkn1a potentially provides a treatment target for cMPNs.

Keywords: Classical myeloproliferative neoplasms, Jak2 ${ }^{\mathrm{V} 617 \mathrm{~F}}$, Stat5a, Dnmt3a, Cdkn1a, GAS

\footnotetext{
*Correspondence: lab7182@mail.tongji.edu.cn; fjf2017@tongji.edu.cn

${ }^{\dagger}$ Jie Zhou and Cheng Guo contributed equally to this work.

${ }^{1}$ Tongji University School of Medicine, Shanghai 200092, China

Full list of author information is available at the end of the article
}

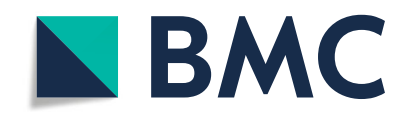

(c) The Author(s). 2021 Open Access This article is licensed under a Creative Commons Attribution 4.0 International License, which permits use, sharing, adaptation, distribution and reproduction in any medium or format, as long as you give appropriate credit to the original author(s) and the source, provide a link to the Creative Commons licence, and indicate if changes were made. The images or other third party material in this article are included in the article's Creative Commons licence, unless indicated otherwise in a credit line to the material. If material is not included in the article's Creative Commons licence and your intended use is not permitted by statutory regulation or exceeds the permitted use, you will need to obtain permission directly from the copyright holder. To view a copy of this licence, visit http://creativecommons.org/licenses/by/4.0/ The Creative Commons Public Domain Dedication waiver (http://creativecommons.org/publicdomain/zero/1.0/) applies to the data made available in this article, unless otherwise stated in a credit line to the data. 


\section{Background}

Classical myeloproliferative neoplasms (cMPNs) are characterized by the overproduction of terminally differentiated blood cells [1], including polycythemia vera (PV), essential thrombocythemia (ET) and primary myelofibrosis (PMF) [2]. The acquired somatic mutation of the tyrosine kinase JAK2 gene $\left(\mathrm{JAK} 2^{\mathrm{V} 617 \mathrm{~F}}\right)$ is the most important pathogenesis of cMPNs [3]. DNA methyltransferase (DNMT) 3a is a de novo methyltransferase [4] which acts as a haplotype tumor suppressor gene in myeloid leukemia. Previous researches have reported the frequent incidence of DNMT3a mutation and disregulation in myeloid leukemia and cMPNs patients [57]. Jacquelin et al. has reported that there is a synergistic carcinogenic effect in $\mathrm{CMPNs}$ driven by $\mathrm{JAK} 2^{\mathrm{V} 617 \mathrm{~F}}$ mutation and DNMT3a deletion, which leads to the activation of inflammatory signals driven by hematopoietic stem and progenitor cell (HSPC) enhancers [6].

These above studies indicated that as well as the JAK2 gene, the DNMT3a gene is also important in the pathogenesis of cMPNs, but their relationship in cMPNs is still a mystery. Few research has answered the question how the Dnmt3a is regulated by Jak2 ${ }^{\mathrm{V} 617 \mathrm{~F}}$ mutation, and its effects on downstream signaling pathways in cMPNs still needs further research.

In order to answer the question, we carried out the present study. Firstly, we found that Dnmt3a was downregulated at the transcriptional and translational levels in Jak2 ${ }^{\mathrm{V} 617 \mathrm{~F}}$-positive BaF3 cells (hereinafter referred to as Jak2 $\left.{ }^{\mathrm{V} 617 \mathrm{~F}} \mathrm{BaF} 3\right)$. Further research showed that the binding of Stat5a protein (which was abnormal activated by the Jak2 ${ }^{\text {V617F }}$ mutation) with Dnmt3a promoter is the mechanism of this downregulation. The gamma-activated sequence (GAS) motif of Stat5a at the region approximately $800 \mathrm{bp}$ upstream of the first exon of the Dnmt3a promoter is the specific site of the binding. Dnmt3a significantly affected the cell proliferation capacity and cell cycle distribution and mediated G0/G1 arrest by suppressing the Cdkn1a via miR-17-5p in Jak2 ${ }^{\mathrm{V} 617 \mathrm{~F}}$ BaF3 cells. This Stat5a/Dnmt3a/miR-17-5p/Cdkn1a regulation axis identified in this study might play an important role in cMPNs and might serve as a potential treatment target for cMPNs.

\section{Methods}

\section{Patients and samples}

A total of 12 samples (six JAK2 $2^{\mathrm{V} 617 \mathrm{~F}}$-positive cMPNs patients and six normal controls) were recruited from Tongji hospital of Tongji University (Table S1, shown in Additional file 1 ). The diagnosis of cMPNs was defined according to World Health Organization (WHO) criteria [8]. The use of clinical samples in our study was according to the Declaration of Helsinki and was approved by the Medical ethic committee of Tongji hospital of Tongji University on Feb. 2021 (Number: 2021-KYSB-177). Written informed consent was obtained from each participant. Mononuclear cells are isolated from bone marrow using density gradient separation (Percoll, Solarbio life sciences, Beijing, China). Total RNA was extracted from bone marrow mononuclear cells using Trizol reagent (Invitrogen, Carlsbad, CA, USA) following the manufacturer's instruction. Total RNA from each sample was quantified by the NanoDrop ND-1000 and RNA integrity was assessed by standard denaturing agarose gel electrophoresis.

\section{Cell lines and cell culture}

The human erythroleukemia cell line HEL, human immortalised myelogenous leukemia cell line K562, human caucasian bone marrow acute myelogenous leukaemia cell line $K G 1 \alpha$, human myeloid leukaemia cell line U937, human myeloid leukaemia cell line NB4, human myeloid leukaemia cell line THP1, the murine pro B cell line BaF3 and 293 T/17 cells were purchased from the Cell Bank, Chinese Academy of Sciences (Shanghai, China) and were characterized using Short Tandem Repeat (STR) markers. HEL, U937, NB4, THP1 and BaF3 cells were grown in Roswell Park Memorial Institute (RPMI) 1640 Medium (Gibco; Thermo Fisher Scientific, Inc.), and wildtype BaF3 cells were grown with $1 \mathrm{ng} / \mathrm{mL}$ IL-3. 293 T/17 cells were grown in Dulbecco's modified Eagle's medium (Gibco; Thermo Fisher Scientific, Inc.). K562 and KG1 $\alpha$ cells were grown in Iscove's Modified Dulbecco's Medium (IMDM, Gibco; Thermo Fisher Scientific, Inc.). All media were supplemented with $1 \%$ penicillin-streptomycin (Gibco; Thermo Fisher Scientific, Inc.) and 10\% fetal bovine serum (FBS; Gibco; Thermo Fisher Scientific, Inc.). All cell lines were cultured in a humidified atmosphere of $5 \% \mathrm{CO}_{2}$ at $37^{\circ} \mathrm{C}$ and were found to be negative for mycoplasma contamination.

\section{Plasmid construction and cell transfection}

Cytokine-dependent wild type BaF3 cells were transformed to Jak2 ${ }^{\mathrm{V} 617 \mathrm{~F}} \mathrm{BaF} 3$ cells with growth factor independence by ectopic expression of Jak $2^{\mathrm{V} 617 \mathrm{~F}}$, resulting in constitutive phosphorylation of Jak2 as well as downstream targets, such as Stat5a. The ectopic expression plasmid of Jak2 $2^{\mathrm{V} 617 \mathrm{~F}}$ was generated by inserting the fulllength Jak2 with Jak2V617F mutation, which was generated by site-directed mutagenesis and confirmed by sequencing, into the pLVX-zsGreen vector (Clontech Laboratories, Inc.). The wild type BaF3 cells transformed empty vector were used as control. The Stat5a overexpression plasmid was generated by inserting the Stat $5 \mathrm{a}$ coding DNA sequence (CDS) into the pLVX-Puro vector. The Dnmt3a overexpression plasmid was generated by inserting the Dnmt3a CDS into the pLVX-zsGreen vector (Clontech Laboratories, Inc.). shRNA lentiviral plasmids targeting Stat5a, Dnmt3a and Cdkn1a were constructed by inserting annealed shRNA template DNA 
sequences into pLVX-shRNA (Clontech Laboratories, Inc.) vector containing either a puromycin resistance cassette or ZsGreen, respectively. The effective targeting shRNA sequences of the Stat5a gene were 5' -GCCAGA TGCAAGTGTTGTA-3' and 5'-GCACCTTCAGATCA ACCAA-3'. The effective targeting shRNA sequences of the Dnmt3a gene were 5' -CCAGATGTTCTTTGCCAA TAA-3' and 5' -GCAGACCAACATCGAATCCAT-3'. The effective targeting shRNA sequences of the Cdkn1a gene were 5' -CCGAGAACGGTGGAACTTT-3' and 5' GCAAAGTGTGCCGTTGTCT-3'. The sequence 5'GCGCGCTTTGTAGGATTCG-3', which is unrelated to any sequence in humans and mice, served as a negative control (shRNA-Ctrl). To produce lentiviral particles, all of the aforementioned plasmids (with two packaging plasmids, pCMV-dR8.2 dvpr and pCMVVSV-G, at a mass ratio of 4:3:2) were cotransfected into $293 \mathrm{~T} / 17$ cells via the calcium phosphate precipitation method (CPT high-efficiency transfection kit, Wuhan Viraltherapy Technologies Co. Ltd) according to the manufacturer's instructions. Cell transfection with lentivirus supernatant was performed with $10 \mu \mathrm{g} / \mathrm{ml}$ polybrene, and GFP or puromycin resistance expression in cells was tested after $48-72 \mathrm{~h}$. As a high level of Stat5a depletion would result in significant inhibition of cell growth and massive cell death, we repeated the construction of stable-transfected cells for each assay. For luciferase reporter plasmids, different promoter regions of Dnmt3a ( $-2860 \mathrm{bp}$ to $+140 \mathrm{bp}$, Table S2, shown in Additional file 2) were cloned into the pmirGLO dual-luciferase expression vector (Promega (Beijing) Biotech Co. Ltd). Luciferase reporter plasmids were transfected into $293 \mathrm{~T} / 17$ cells via the calcium phosphate precipitation method. RNAFit reagent was used for transfection of miRNAs following the manufacturer's protocol (Hanbio Technology (Shanghai) Co. Ltd).

\section{Reagents, chemicals, and antibodies}

Stat5a inhibitor AZ960 (cat. no. S2214) and LY2784544 (cat. no. S2179) were obtained from Selleckchem (USA) and dissolved in DMSO (Sigma-Aldrich; Merck KGaA). Primary antibodies against Jak2 (cat. no. 3230), p-Jak2 (cat. no. 3771), Stat5a (cat. no. 94205), p-Stat5a (cat. no. 4322), Dnmt3a (cat. no. 3598), $\beta$-actin (cat. no. 8457) and Cdkn1a (cat. no. 64016) were purchased from Cell Signaling Technology (USA). Mmu-miR-17-5p (hereinafter referred to as miR-17-5p) mimic, related mimics control, inhibitor and related inhibitor control were got from GenePharma (China). The sequences of miRNA were listed in Table 1.

\section{Western blotting}

Total protein was extracted with RIPA buffer (Epizyme Biotech, cat. no. P1101) containing protease inhibitor cocktail (Beyotime Biotechnology, cat. The BCA method (Beyotime Biotechnology, cat.no. P0011) was used to detect the protein concentration. Equal amounts of total protein $(30 \mu \mathrm{g})$ were separated by protein electrophoresis on a 10\% SDS-PAGE gel and transferred onto PVDF membranes (Millipore, Billerica, MA). The membranes were probed with the indicated antibodies. Protein bands were detected and quantified by Amersham Imager 600 (GE Healthcare).

\section{Dual-luciferase reporter assay}

293 T/17 cells were co-transfected with different luciferase reporter plasmids and a Stat5a overexpression plasmid for $48 \mathrm{~h}$ for the luciferase reporter assay of the Dnmt3a promoter. Luciferase activities were measured with the Dual Luciferase Reporter Gene Assay Kit (Beyotime Biotechnology, cat.no. RG027). Data were normalized by calculating the ratio between firefly and Renilla luciferase activity.

\section{Cell counting assay for proliferation detection}

Cells in good growth conditions to be tested were centrifuged, the supernatant was removed, new medium was added, and the cells were resuspended by gentle blowing, and cell counting was performed. Fifty cells were inoculated in each well of a 24-well plate and incubated in a humidified atmosphere of $5 \% \mathrm{CO}_{2}$ at $37^{\circ} \mathrm{C}$. A total of 5 groups of 3 wells each were counted. The cells were counted in one group every three days from the 4th day of incubation. The cell growth curve was plotted as a line graph based on the count of each group of cells.

\section{Soft agarose colony formation assay}

The 1\% agarose solution was prepared with ultrapure water, autoclaved at $121^{\circ} \mathrm{C}$ for $15 \mathrm{~min}$, placed in a water bath at $42{ }^{\circ} \mathrm{C}$, mixed with $2 \times$ complete medium containing $20 \% \mathrm{FBS}$ in equal volumes to make the final concentration of agarose $0.5 \%$, and poured rapidly into 6-well

Table 1 Sequences of miRNA mimic, related mimics control, inhibitor and related inhibitor control

\begin{tabular}{lll}
\hline & Sense 5'-3' & Antisense 5'-3' \\
\hline miR-17-5p mimic & CAAAGUGCUUACAGUGCAGGUAG & ACCUGCACUGUAAGCACUUUGUU \\
miR-17-5p inhibitor & CUACCUGCACUGUAAGCACUUUG & $/$ \\
Negative control $(\mathrm{NC})$ & UUCUCCGAACGUGUCACGUTT & ACGUGACACGUUCGGAGAATT \\
Inhibitor NC $(\mathrm{NC}$ in) & CAGUACUUUUGUGUAGUACAA & $/$ \\
\hline
\end{tabular}


cell culture plates at $4 \mathrm{~mL}$ per well. Equilibrate the 6well cell culture plates in a $37^{\circ} \mathrm{C}$ incubator for more than $30 \mathrm{~min}$ before use. The prepared $0.7 \%$ agarose solution was placed in a $42{ }^{\circ} \mathrm{C}$-water bath. The cells were resuspended in single-cell suspensions with culture medium, counted, and diluted to $1 \times 10^{3}$ cells $/ \mathrm{mL}(100$ cells per well). Then, $0.2 \mathrm{~mL}$ of the cytosol, $2 \mathrm{~mL}$ of $2 \times$ cell culture medium containing $20 \% \mathrm{FBS}$ and $2 \mathrm{~mL}$ of $0.7 \%$ agarose were added to each tube, mixed well and spread on the bottom agar layer $(2 \mathrm{~mL}$ per well, with 3 replicate wells in total). After solidification at room temperature, the 6-well cell culture plates were incubated at $37^{\circ} \mathrm{C}$ for $14 \mathrm{~d}$. Cells were observed under a microscope after continuous culture for $14 \mathrm{~d}$. The number of colonies with more than 10 cells was counted.

\section{Cell cycle distribution analysis}

For cell cycle distribution analysis, BrdU solution was added to the medium at a final concentration of $10 \mathrm{ng} / \mathrm{ml}$. After culturing at $37^{\circ} \mathrm{C}$ for $2 \mathrm{~h}$, the cells were collected, washed twice with PBS and fixed with 95\% ethanol overnight at $4{ }^{\circ} \mathrm{C}$. The next day, the cells were washed twice with PBS buffer (1\% FBS, 0.09\% NaN3). The cells were resuspended in $2 \mathrm{ml}$ of PBS buffer $(2 \mathrm{~N} \mathrm{HCl}$ and $0.5 \%$ Triton $\mathrm{X}-100)$ and incubated in the dark for $30 \mathrm{~min}$ at room temperature. The cells were washed once with $1 \mathrm{ml}$ of PBS and resuspended in $0.5 \mathrm{ml}$ of $0.1 \mathrm{M} \mathrm{Na}_{2} \mathrm{~B}_{4} \mathrm{O}_{7}$ for 2 $\mathrm{min}$. The cells were washed again and resuspended in $50 \mu \mathrm{l}$ of the anti-BrdU APC antibody solution (diluted with staining buffer at 1:20; cat. no. ab136650, Abcam) and incubated for $30-60 \mathrm{~min}$. Then, $5 \mu \mathrm{l}$ of PI staining solution was added and incubated for $10 \mathrm{~min}$. The cell cycle distribution was determined by a flow cytometer (BD Biosciences) and analyzed by FlowJo V10.

\section{RNA extraction and qPCR}

Total RNA was extracted with a Quick-RNA MicroPrep RNA Extraction Kit (Zymo Research, USA), cDNA of coding genes was produced by PrimeScript RT Master Mix (Takara, Japan), and cDNA of miRNAs was produced by TransScript miRNA First-Strand cDNA Synthesis SuperMix (Transgene, China). The ChamQ Universal SYBR qPCR Master Mix Kit (Vazyme, China) was used to detect relative mRNA expression by a LightCycler 96 system (Roche, Switzerland) with 40 cycles of PCR thermocycling. The primer sequences were as follows: For BaF3 cells: $\beta$-actin forward, $5^{\prime}$-GTGACG TTGACATCCGTAAAGA-3' and reverse, 5'-GCCGGACT CATCGTA CTCC-3'; Dnmt3a forward, 5'-GATGAGCC TGAGTATGAGGATGG-3' and reverse, 5' -CAAGA CACAATTCGGCCTGG-3'; Stat5a forward, 5'-CAGATG CAAGTGTTGTATGGGC-3' and reverse, $5^{\prime}$-GCTGGCTC TCGATCCACTG-3'; Cdkn1a forward, 5'-CCTGGTGATG TCCGAC CTG-3' and reverse, 5'-CCATGAGCGCATCG CAATC-3'. For specimens of cMPN patients and normal controls: DNMT3a forward, 5'-GGAGGACCGAAAGG ACGGA-3' and reverse, 5'-CCCCATTGGGTAATAGCT CTGAG-3'; $\beta$-actin forward, 5 '-CATGTACGTTGCTATC CAG GC-3' and reverse, 5'-CTCCTTAATGTCACGCAC GAT-3'; Cdkn1a forward, 5'-TGTCCGTCAGAACCCATG C-3' and reverse, 5'-AAAGTCGAAGTTCCATCGCTC-3'. The mRNA expression of the target gene was calculated by the $2^{-\Delta \Delta C t}$ method [9] or relative to $\beta$-actin expression. The PerfectStrat Green qPCR SuperMix was used to detect relative miRNA expression with 45 cycles of PCR thermocycling. The miRNA relative expression was calculated by the $2^{-\Delta \Delta C t}$ method using U6 small nucleolar RNA gene as internal reference. The forward primer of miR-17-5p is $5^{\prime}$-GCTTCG CAAAGTGCTTACAGTGC-3', and the forward primer of U6 is GCTTCGGCAGCACATATACTAAAAT. The reverse primer of qPCR for miRNA is provided in the TransScript miRNA First-Strand cDNA Synthesis SuperMix named as Universal miRNA qPCR Primer.

\section{Chromatin immunoprecipitation (ChIP) assays}

ChIP assays were performed using a ChIP assay kit (Abcam, cat. ab117138) according to the manufacturer's instructions. Briefly, cells were fixed for $8 \mathrm{~min}$ with $1 \%$ free formaldehyde (Cell Signaling Technology, cat. no. 12606) and then disrupted in SDS lysis buffer. Chromatin was sonicated by an M220 Focused-ultrasonicator (Covaris, Inc.) to shear DNA to an average length ranging from 200 to $1000 \mathrm{bp}$, as verified by agarose gel electrophoresis. Next, chromatin was immunoprecipitated with antibodies $(2 \mu \mathrm{L})$ directed against Stat $5 \mathrm{a}$, and $0.8 \mu \mathrm{L}$ of nonimmune IgG was used as the negative control. Final DNA extractions were quantitative-PCR amplified using primer pairs that cover the sequence in the Dnmt3a promoter region ( $-2860 \mathrm{bp}$ to $+140 \mathrm{bp}$ ). Sequences of the primers for quantitative PCR are listed in Table 2. For the primers numbered Dnmt3a-1F and Dnmt3a-1R, the amplified fragments are numbered ChIP1, and so on.

\section{Statistical analysis}

The statistical analyses were performed with GraphPad Prism 7 software. The results were from triplicate experiments, and the data are presented as the mean $\pm S D$ (standard deviation). The significance of mean values was determined by unpaired two-tailed Student's $\mathrm{t}$ test $(p$ value cut-offs: $\left.{ }^{* * * * *} \mathrm{p}<0.0001,{ }^{* * *} \mathrm{p}<0.001,{ }^{* *} \mathrm{p}<0.01,{ }^{*} \mathrm{p}<0.05\right)$ and the Type I error for all statistical tests is $\alpha=0.05$.

\section{Results}

Dnmt3a expression is repressed by Stat5a at the transcriptional and translational levels in Jak2 $2^{\mathrm{V} 617 \mathrm{~F}}$ positive BaF3 cells and bone marrow mononuclear cells of CMPN patients

In this study, we mimicked JAK2 ${ }^{\mathrm{V} 617 \mathrm{~F}}$ mutation-positive cMPNs in vitro by overexpressing the murine Jak2 gene 
Table 2 Primers for quantitative PCR of the Dnmt3a promoter region

\begin{tabular}{|c|c|c|}
\hline Number & Primer & Sequences $\left(5^{\prime}-3^{\prime}\right)$ \\
\hline \multirow[t]{2}{*}{1} & Dnmt3a-1F & GGAATGAGGTGGAGTCCTGA \\
\hline & Dnmt3a-1R & CATGGCCATAGGACAGAGGT \\
\hline \multirow[t]{2}{*}{2} & Dnmt3a-2F & ACCTCTGTCCTATGGCCATG \\
\hline & Dnmt3a-2R & CCCCAGTCCCTGACAGTG \\
\hline \multirow[t]{2}{*}{3} & Dnmt3a-3F & CACTGTCAGGGACTGGGG \\
\hline & Dnmt3a-3R & GTGGGTCACGACCTCTITGA \\
\hline \multirow[t]{2}{*}{4} & Dnmt3a-4F & TCAAAGAGGTCGTGACCCAC \\
\hline & Dnmt3a-4R & GGGCACTTTCTCCCTGAAGT \\
\hline \multirow[t]{2}{*}{5} & Dnmt3a-5F & ACTTCAGGGAGAAAGTGCCC \\
\hline & Dnmt3a-5R & TGTCAGGGGACTGAGCTCTT \\
\hline \multirow[t]{2}{*}{6} & Dnmt3a-6F & AAGAGCTCAGTCCCCTGACA \\
\hline & Dnmt3a-6R & CACTGTTAGAGCAATCGGATGA \\
\hline \multirow[t]{2}{*}{7} & Dnmt3a-7F & TAGCCCTGGCTGTATTGGA \\
\hline & Dnmt3a-7R & GCCTGAATTTGATTCCCAGA \\
\hline \multirow[t]{2}{*}{8} & Dnmt3a-8F & TITGTGCCTGGTCTCCTTC \\
\hline & Dnmt3a-8R & AGCTTGATGGCAGAGTGCTT \\
\hline
\end{tabular}

with the V617F mutation in the mouse pro- $\mathrm{B}$ cell line BaF3 and used wild-type BaF3 cells transfected with empty vector as controls. Firstly, in Jak2 ${ }^{\mathrm{V} 617 \mathrm{~F}} \mathrm{BaF} 3$ cells, the JAK-STAT pathway was abnormally activated, which resulted in the elevated expression of the Jak2, p-Jak2, Stat5a and p-Stat5a proteins (Fig. 1A; Supplementary Fig. 1). Moreover, we found that the expression level of Dnmt3a protein was decreased in Jak2 ${ }^{\mathrm{V} 617 \mathrm{~F}} \mathrm{BaF} 3$ cells compared with control BaF3 cells (Fig. 1A; Supplementary Fig. 1). Bone marrow mononuclear cells were isolated from $\mathrm{JAK}_{2}{ }^{\mathrm{V} 617 \mathrm{~F}} \mathrm{cMPN}$ patients and the normal controls. The expression of DNMT3a in bone marrow mononuclear cells were detected by RT-qPCR, and the results showed that DNMT3a was less transcribed in cMPN patients with JAK2 ${ }^{\mathrm{V} 617 \mathrm{~F}}$ mutation compared with the normal controls (Fig. 1B), which was consistent with the result observed in Jak2 ${ }^{\mathrm{V} 617 \mathrm{~F}} \mathrm{BaF} 3$ cells. We then incubated Jak2 ${ }^{\mathrm{V} 617 \mathrm{~F}}$ BaF3 cells with two JAK-STAT pathway inhibitors, AZ960 and LY2784544, to verify that the decreased protein level of Dnmt3a was indeed associated with abnormal activation of the Jak-Stat pathway. It showed that the expression level of Dnmt3a increased gradually with the gradual suppression of p-Stat5a expression, indicating that the protein levels of Dnmt3a was truely negatively regulated by activated Jak-Stat

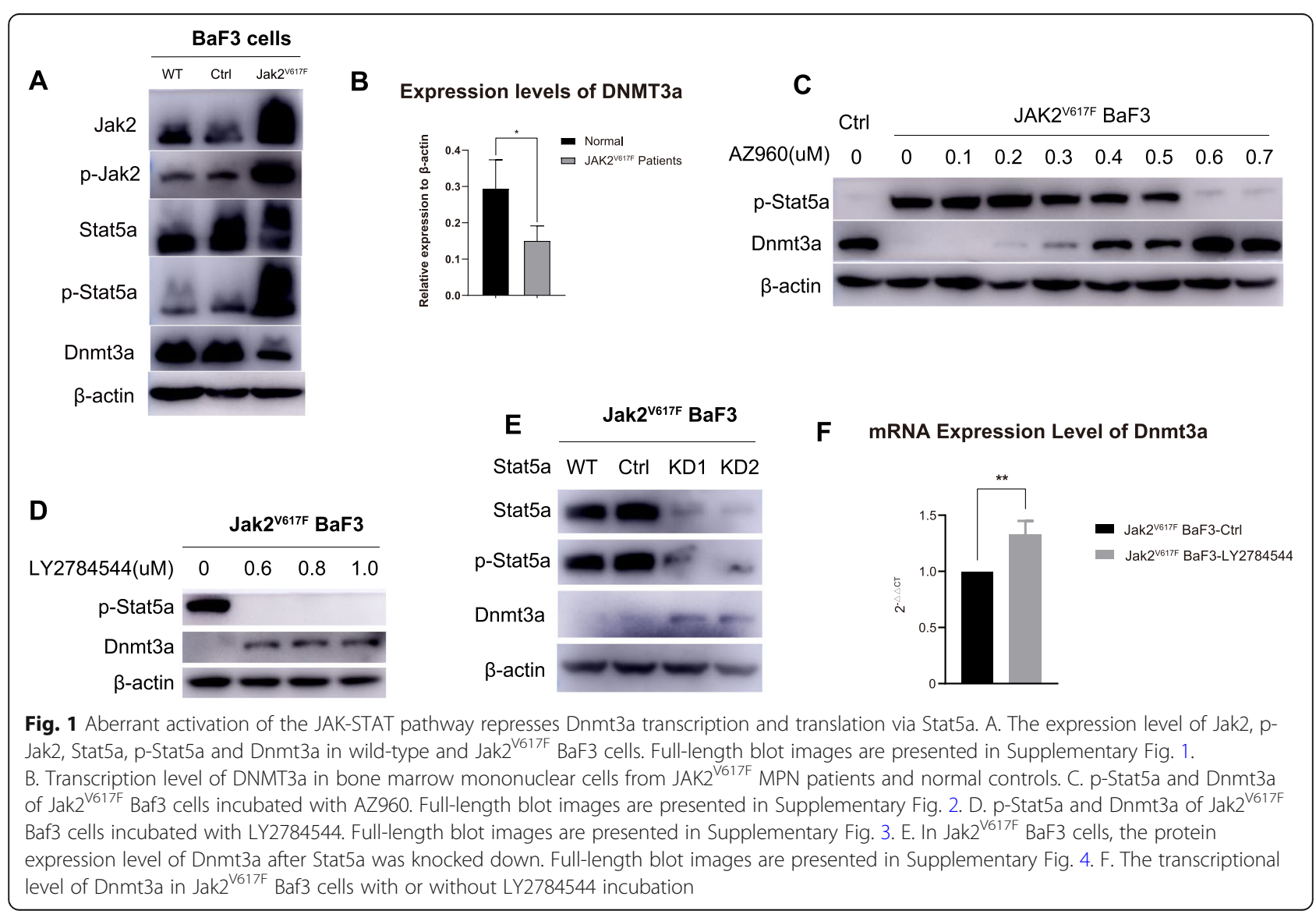


pathway especially activated Stat5a (Fig. 1C and Supplementary Fig. 2; Fig. 1D and Supplementary Fig. 3). To avoid the off-target effect of Jak-Stat pathway inhibitors, Stat5a-knockdown stable Jak2 ${ }^{\mathrm{V} 617 \mathrm{~F}}$ BaF3 cell lines was also constructed and the elevated protein expression level of Dnmt3a was observed in this stable cell line (Fig. $1 \mathrm{E}$ and Supplementary Fig. 4). RT-qPCR assays showed that inhibition of Stat5a by LY2784544 incubation led to upregulation of Dnmt3a transcriptional levels (Fig. 1F). These results firmed from different aspects that the Dnmt3a was negatively regulated in Jak $2^{\mathrm{V} 617 \mathrm{~F}}$ positive cells owing to the abnormal activation of Jak-Stat pathway caused by Jak2 $2^{\mathrm{V} 617 \mathrm{~F}}$ mutation.

\section{Experiments in myeloid tumor cell lines further confirm that the Dnmt3a expression is repressed by Stat5a and Stat5a is the upstream regulator of Dnmt3a}

In order to supply more evidence to prove that the Dnmt3a is downregulated by Stat5a, the expression levels of p-STAT5a and DNMT3a proteins in other human or murine myeloid tumor cell lines were examined, as shown in Fig. 2A (Supplementary Fig. 5) and Fig. 2B (Supplementary Fig. 6). In Fig. 2A, we selected six human myeloid tumor cell lines, of which the HEL cell line is a human erythroleukemia cell line with the JAK2 $2^{\mathrm{V} 617 \mathrm{~F}}$ mutation, while all other cell lines do not carry the JAK2 ${ }^{\mathrm{V} 617 \mathrm{~F}}$ mutation. The $\mathrm{p}$-STAT5a expression level was most significant in the HEL cell line, indicating that the JAK-STAT pathway was activated in HEL cells. In HEL, KG1 $\alpha$ and K562 cells, the expression levesl of pSTAT5a were higher and the expression levels of DNMT3a protein were correspondingly lower. In contrast, p-STAT5a expression levels were lower in U937 and THP1 cells, and the protein expression levels of DNMT3a were higher. In Fig. 2B, we selected wild-type BaF3 cells, BaF3 cells with the Bcr-abl fusion gene and $\mathrm{BaF} 3$ cells with the Jak2 ${ }^{\mathrm{V} 617 \mathrm{~F}}$ mutation to detect the expression levels of p-Stat5a and Dnmt3a. Similar to the aforementioned assay, p-Stat5a expression was the highest in Jak2 $2^{\mathrm{V} 617 \mathrm{~F}} \mathrm{BaF} 3$ cells, while the expression level of Dnmt3a was correspondingly the lowest.

To further confirm that this effect is mediated by the Stat5a protein, Stat5a knockdown and overexpression cell lines using wild-type BaF3 cells were constructed as shown in Fig. 2C (Supplementary Fig. 7) and Fig. 2D (Supplementary Fig. 8). In wild-type BaF3 cells without Jak2 $2^{\mathrm{V} 617 \mathrm{~F}}$ mutation, the protein expression level of Dnmt3a increased as Stat5a was knocked down. Conversely, the protein expression level of Dnmt3a decreased with overexpression of Stat5a. These results indicated that the Stat5a protein is the key factor affecting the expression of Dnmt3a protein, and the inhibition of Dnmt3a in Jak2 ${ }^{\mathrm{V} 617 \mathrm{~F}} \mathrm{BaF} 3$ cells is caused by abnormal activation of Stat5a.
We also altered the expression level of Dnmt3a in Jak2 ${ }^{\mathrm{V} 617 \mathrm{~F}}$ BaF3 cells (Fig. 2E and Supplementary Fig. 9; Fig. 2F and Supplementary Fig. 10) and wild-type BaF3 cells (Fig. 2G and Supplementary Fig. 11; Fig. 2H and Supplementary Fig. 12), and found that neither Dnmt3a knockdown nor overexpression had any effect on the protein expression of Stat5a, which further verified that Stat5a was the upstream regulator of Dnmt3a.

In conclusion, all of the above results confirmed that the Dnmt3a is negatively regulated by the Stat5a protein and Stat5a is the upstream regulator of Dnmt3a.

\section{The Stat5a protein binds with the GAS motif region of Dnmt3a promoter and suppresses the transcriptional activity of Dnmt3a promoter}

To investigate the mechanism by which Stat5a regulates the transcriptional level of Dnmt3a, we selected the region approximately $3000 \mathrm{bp}$ upstream of the first exon of the Dnmt3a gene for amplification and constructed dual-luciferase plasmids with different truncation ranges, named them respectively as $\mathrm{P} 1, \mathrm{P} 2, \mathrm{P} 3, \mathrm{P} 4, \mathrm{P}^{3 / 4}$, Region1, Region2, and Region3 (Fig. 3A). After incubation with the Stat5a inhibitor LY2784544 for $2 \mathrm{~h}$, it was found that the fluorescence intensity was significantly increased in $293 \mathrm{~T}$ cells transfected with the P4 region luciferase plasmid, while in the $293 \mathrm{~T}$ cells transfected with the $\mathrm{P}^{3 / 4}$ plasmid which except for the P4 region, showed no significant change in fluorescence intensity after incubation with LY2784544 for the same time (Fig. 3B). Furthermore, LY2784544 incubation of $293 \mathrm{~T}$ cells transfected with the P1, P2, P3, R1, R2 and R3 regions of Dnmt3a promoter showed no significant change in relative fluorescence intensity (Fig. 3B and Fig. 3C). These results indicated that inhibition of the protein level of Stat $5 \mathrm{a}$ significantly increased the transcriptional activity of the Dnmt3a promoter, and we hypothesized that promoter region of Dnmt3a might locate at $\mathrm{P} 4$, which was located in the region approximately $800 \mathrm{bp}$ upstream of the first exon. Next, we examined the time effect of inhibitor incubation on the fluorescence intensity. The results showed that the $\mathrm{P} 4$ region promoter transcriptional activity was the strongest after $3 \mathrm{~h}$ of inhibitor incubation (Fig. 3D). Thereafter, by overexpressing Stat5a in $293 \mathrm{~T}$ cells and adding IL-3 to simulate the abnormal activation and phosphorylation of Stat5a, we found that overexpression and activation of Stat5a inhibited the transcriptional activity of the $\mathrm{P} 4$ region promoter (Fig. $3 \mathrm{E}$ and Supplementary Fig. 13; Fig. 3F), indicating that the activation and phosphorylation of Stat5a did inhibit the transcriptional activity of Dnmt3a promoter, which will in turn induce downregulation of the protein expression level of Dnmt3a.

To investigate the specific site of the Dnmt3a promoter at which Stat5a binds to, we predicted it using the 


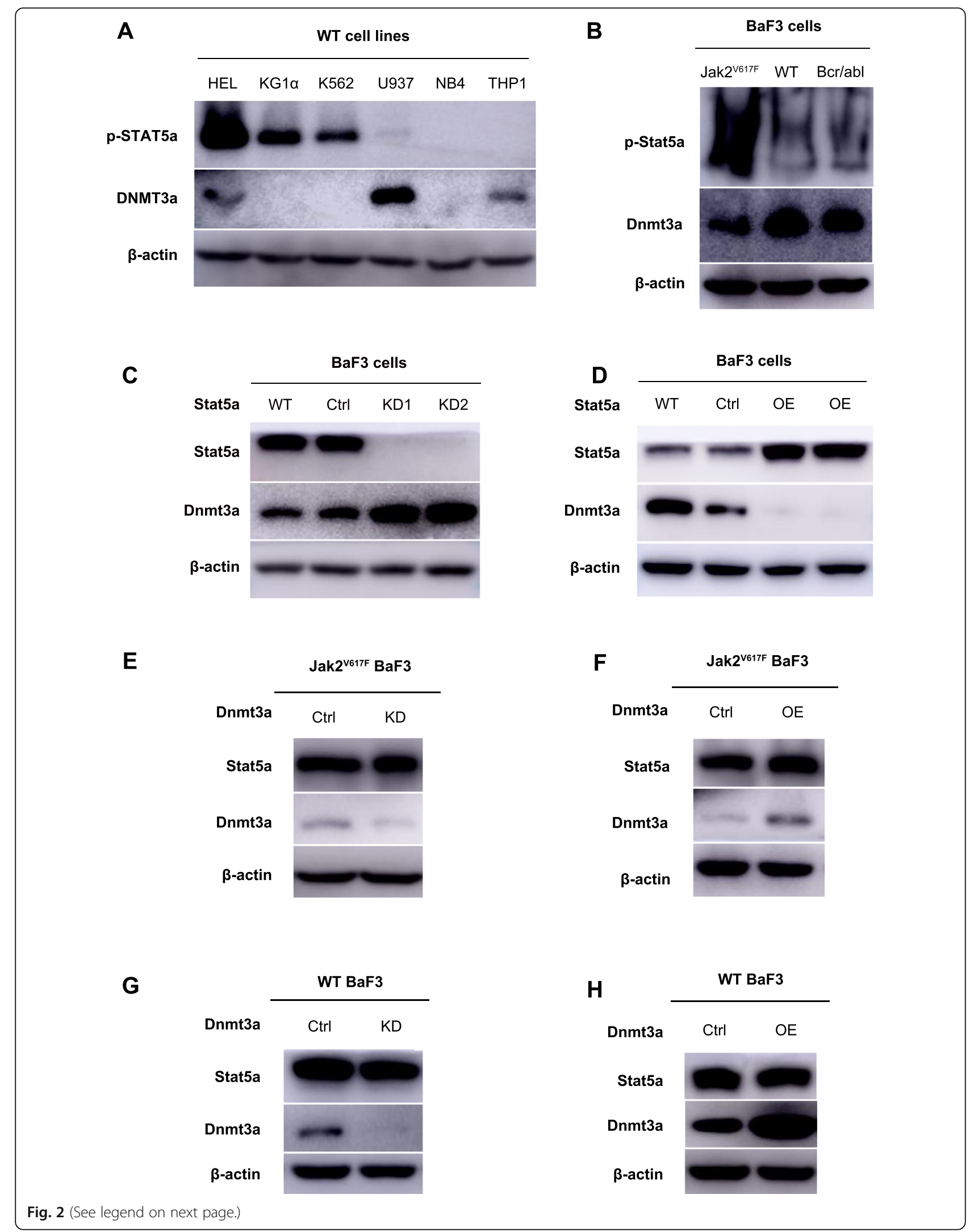


(See figure on previous page.)

Fig. 2 Dnmt3a expression is repressed by Stat5a and Stat5a is the upstream regulator of Dnmt3a. A. The expression levels of p-STAT5a and DNMT3a proteins in human myeloid tumor cell lines. Full-length blot images are presented in Supplementary Fig. 5. B. The expression levels of p-Stat5a and Dnmt3a proteins in murine myeloid tumor cell lines. Full-length blot images are presented in Supplementary Fig. 6. C. In wild type BaF3 cells, the protein expression level of Dnmt3a after Stat5a was knocked down. Full-length blot images are presented in Supplementary Fig. 7. D. In wild type BaF3 cells, the protein expression level of Dnmt3a after overexpression of Stat5a. Full-length blot images are presented in Supplementary Fig. 8. E \& F. In Jak2 ${ }^{\mathrm{V} 617 \mathrm{~F}}$ BaF3 cells, the protein expression of Stat5a after knockdown or overexpression of Dnmt3a. Full-length blot images are presented in Supplementary Fig. 9 and Supplementary Fig. 10. G \& H. In wildtype BaF3 cells, the protein expression of Stat5a after knockdown or overexpression of Dnmt3a. Full-length blot images are presented in Supplementary Fig. 11 and Supplementary Fig. 12

JASPAR database (http://jaspar.genereg.net/). The gamma-activated sequence motif (GAS) which was well reported to be binded with STAT5a protein [10] is found to be located at the P4 promoter region of Dnmt3a. So we next mutated the GAS motif sequence in Dnmt3a from TTCTGGGAA to TAAACCTGG to construct a dual-luciferase plasmid of the mutated P4 region (named GASmut). As shown in Fig. 3G, the transcriptional activity of $\mathrm{P} 4$ promoter region was significantly higher when cells were incubated with LY2784544. However, after the GAS motif in P4 was mutated, the LY2784544 incubation failed to elevate the transcriptional activity of $\mathrm{P} 4$ promoter region. The above results suggest that Stat5a negatively regulates Dnmt3a probably by regulating the transcriptional activity of the promoter, and the specific binding site of regulation may be within the GAS motif and its nearby regions.

Then, we performed ChIP assays to find out whether Stat5a protein binds to the promoter of Dnmt3a directly. qPCR primers were designed to cover the full-length sequence of $3000 \mathrm{bp}$ upstream of the first exon of Dnmt3a, with a schematic diagram shown in Fig. 4A. Results of ChIP assays (Fig. 4B and C, Supplementary Fig. 14) identified that the Stat5a protein occupied several regions of the Dnmt3a promoter (ChIP1, ChIP6 and ChIP7). In addition, the GAS site in Fig. 3 was located in the ChIP7 fragment ( $-556 \mathrm{bp} \sim-330 \mathrm{bp}$ ), which further confirmed our hypothesis that the promoter region of Dnmt3a might locate in approximately $800 \mathrm{bp}$ upstream of the first exon, and indicated that Stat5a regulated the transcriptional activity of the Dnmt3a promoter by occupying the GAS motif and its nearby regions of the promoter.

Taken together, these results demonstrated that the direct binding between Stat5a protein and Dnmt3a promoter mediated the inhibited transcription and expression of Dnmt3a.

\section{Dnmt3a suppresses the proliferation capacity of Jak2 ${ }^{\mathrm{V} 617 \mathrm{~F}}$ BaF3 cells}

To investigate the effect of Dnmt3a on the proliferation ability of Jak $2^{\mathrm{V} 617 \mathrm{~F}}$ BaF3 cells, we constructed Dnmt3a silencing and overexpression plasmids, and the corresponding stably transformed Jak2 $2^{\mathrm{V} 617 \mathrm{~F}} \mathrm{BaF} 3$ cell lines were constructed using lentiviral infection techniques. The in vitro clonogenic ability was detected by soft agar clone formation, and we found that the clonogenic ability of Jak2 ${ }^{\text {V617F }}$ BaF3 cells with Dnmt3a overexpression was diminished (Fig. 5A and Fig. 5B), while the clonogenic ability of Jak2 ${ }^{\mathrm{V} 617 \mathrm{~F}} \mathrm{BaF} 3$ cells with Dnmt3a knockdown was enhanced (Fig. 5A and Fig. 5C). Then, we performed cell counting assays on stably transduced Jak2 ${ }^{\text {V617F }}$ BaF3 cells with Dnmt3a knockdown or overexpression. As shown in Fig. 5D, the proliferation level of Jak2 ${ }^{\mathrm{V} 617 \mathrm{~F}} \mathrm{BaF} 3$ cells overexpressing Dnmt3a was reduced, while the proliferation ability of Jak2 ${ }^{\text {V617F }}$ BaF3 cells with Dnmt3a knockdown was enhanced. In conclusion, the above results indicate that Dnmt3a significantly downregulates the proliferation capacity of Jak2 $2^{\mathrm{V} 617 \mathrm{~F}}$ cells.

\section{Dnmt3a mediates G0/G1 arrest by positive-regulating the Cdkn1a expression in Jak2 ${ }^{\mathrm{V} 617 \mathrm{~F}}$ cells}

To clarify how Dnmt3a suppresses the proliferation capacity of Jak $2^{\mathrm{V} 617 \mathrm{~F}}$ cells, we performed cell cycle distribution analysis. As shown in Fig. 6A-Fig. 6D, compared with the control Jak $2^{\mathrm{V} 617 \mathrm{~F}}$ BaF3 cells, Dnmt3aknockdown (Dnmt3a KD) Jak2 ${ }^{\mathrm{V} 617 \mathrm{~F}} \mathrm{BaF} 3$ cells had significantly increased $\mathrm{S}$-phase cell proportion and decreased G0/G1-phase cell proportion, while Dnmt3a overexpression (Dnmt3a OE) Jak2 ${ }^{\mathrm{V} 617 \mathrm{~F}} \mathrm{BaF} 3$ cells had significantly increased G0/G1-phase cell proportion and decreased S-phase cell proportion. These results indicates that Dnmt3a can inhibit the cell cycle progression of Jak2 $2^{\mathrm{V} 617 \mathrm{~F}} \mathrm{BaF} 3$ cells, mediates $\mathrm{G} 0 / \mathrm{G} 1$ arrest and results in the suppression of the proliferation of Jak $2^{\mathrm{V} 617 \mathrm{~F}}$ BaF3 cells at last.

How does Dnmt3a mediate G0/G1 arrest? In order to answer this question, we firstly tested the expression of cell cycle-related gene Cdkn1a. The Cdkn1a gene encodes a potent cyclin-dependent kinase inhibitor that binds to and inhibits the activity of cyclin-dependent kinase 2 or the cyclin-dependent kinase 4 complex, therefore plays a role in regulating the progression of the cell cycle in the G1 phase, causing the G1 phase of the cell cycle to arrest [11]. We found that the expression level of Cdkn1a was significantly suppressed in Jak2 ${ }^{\mathrm{V} 617 \mathrm{~F}} \mathrm{BaF} 3$ cells compared with control BaF3 cells (Fig. 7A and Supplementary Fig. 15; Fig. 7B). Furthermore, the expression of Cdkn1a in 


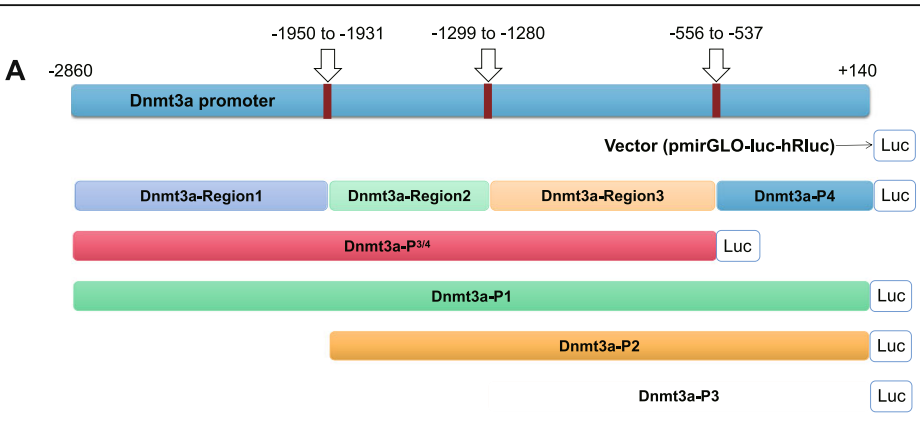

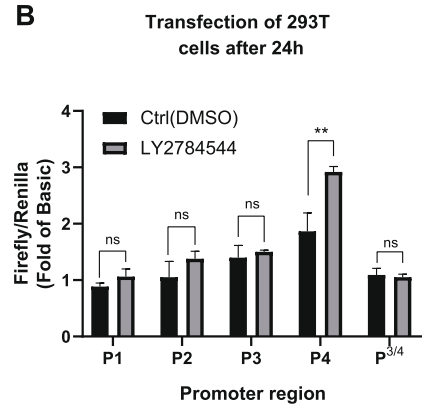

D

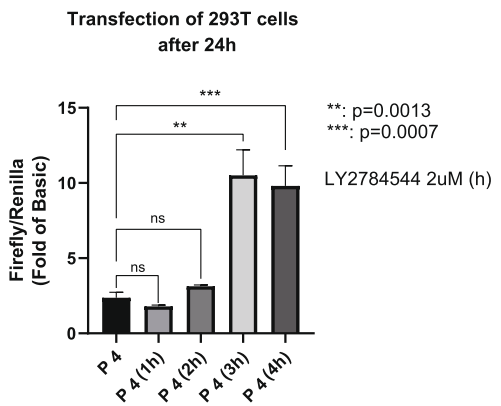

$\mathbf{F}$

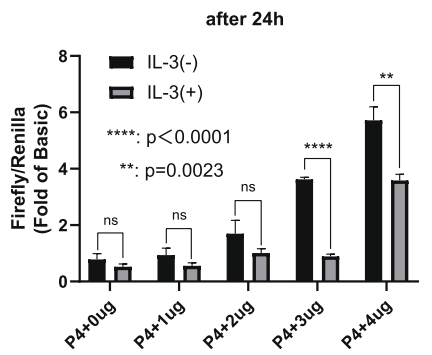

C Transfection of $293 \mathrm{~T}$ cells after $24 \mathrm{~h}$

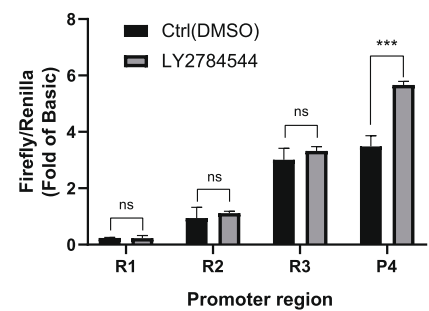

E

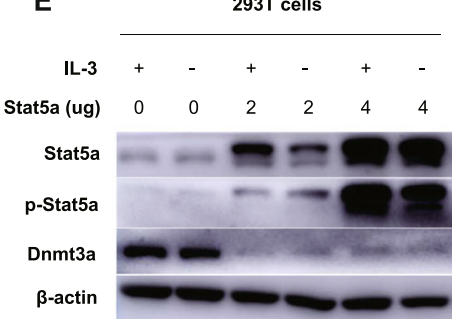

G

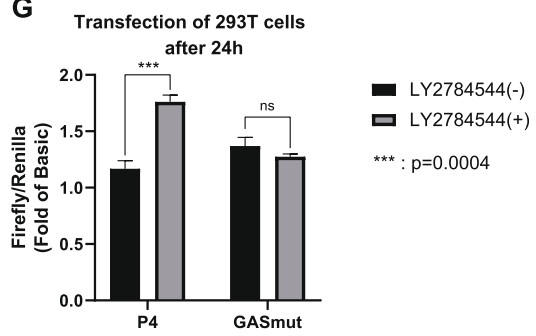

Fig. 3 Aberrant activation of Stat5a downregulates the promoter transcriptional activity of Dnmt3a. A. Segments of the promoter region of the Dnmt3a gene. B \& C. Incubation with LY2784544 significantly increased the fluorescence intensity of 293 T cells transfected with the P4 region luciferase plasmid. D. The P4 region promoter transcriptional activity was strongest after $3 \mathrm{~h}$ of LY2784544 incubation. E. Stat5a was overexpressed in 293 T cells, and IL-3 was added to simulate the abnormal activation and phosphorylation of Stat5a. Full-length blot images are presented in Supplementary Fig. 13. F. Overexpression and activation of Stat5a inhibited the transcriptional activity of the P4 region promoter. G. The effect of LY2784544 on transcriptional activity of the Dnmt3a promoter with or without mutated GAS

$\mathrm{JAK} 2^{\mathrm{V} 617 \mathrm{~F}} \mathrm{cMPN}$ patients and normal controls were examined and the results showed that Cdkn1a expression levels in $\mathrm{JAK} 2^{\mathrm{V} 617 \mathrm{~F}} \mathrm{cMPN}$ patients were lower than that in normal controls, which was consistent with the results in BaF3 cell models (Fig. 7C). Collectively, the above results show that the expression of the Cdkn1a is downregulated in Jak2 ${ }^{\mathrm{V} 617 \mathrm{~F}}$ cells. Secondly, we explored the role of Dnmt3a in the downregulation of Cdkn1a. We detected 


\section{A}

$-2860$

$+140$

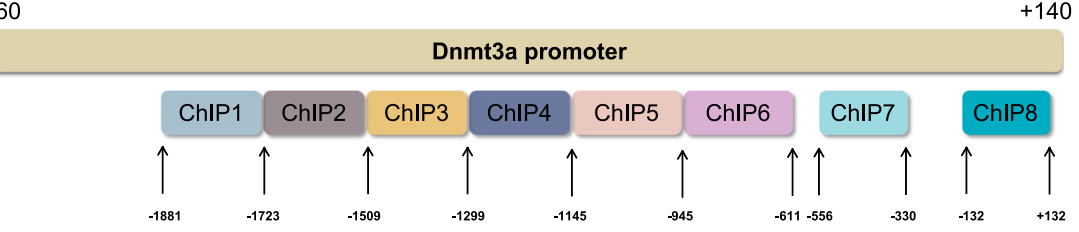

B

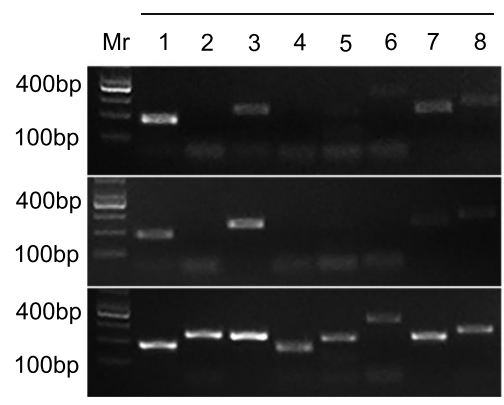

c

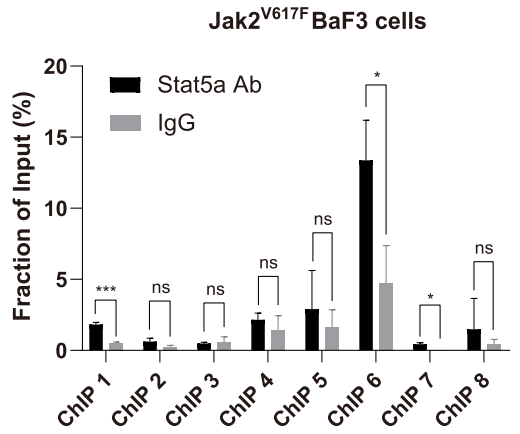

Fig. 4 Stat5a downregulates Dnmt3a protein expression by directly binding to the Dnmt3a promoter. A. The schema of the 8 regions of ChIP analysis; B \& C. Stat5a protein occupied several regions (ChIP1, ChIP6 and ChIP7) of the Dnmt3a promoter. Full-length blot images are presented in Supplementary Fig. 14
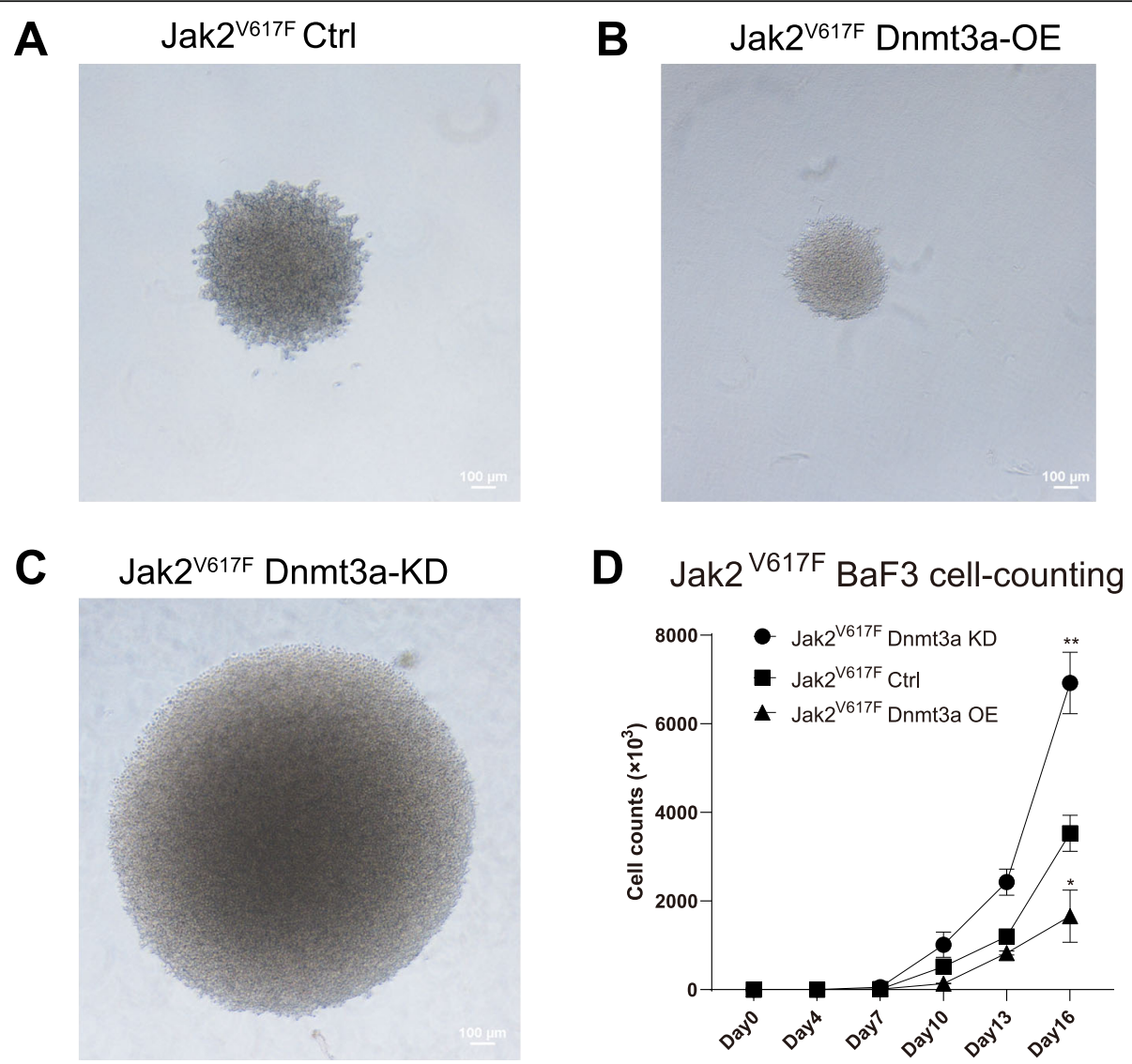

Fig. 5 Knockdown or overexpression of Dnmt3a in Jak2 ${ }^{\mathrm{V} 617 \mathrm{~F}}$ BaF3 cells significantly affects cell proliferation capacity. A. Soft agar clone formation of Jak2 ${ }^{\mathrm{V} 617 \mathrm{~F}}$ BaF3 cells; B. Soft agar clone formation of Dnmt3a-overexpressing Jak2 ${ }^{\mathrm{V} 617 \mathrm{~F}}$ BaF3 cells; C. Soft agar clone formation of Dnmt3aknockdown Jak2 ${ }^{\mathrm{V} 617 \mathrm{~F}}$ BaF3 cells; D. Cell proliferation level of Jak2 ${ }^{\mathrm{V} 617 \mathrm{~F}}$ BaF3 cells with Dnmt3a overexpression or with Dnmt3a knockdown 
A

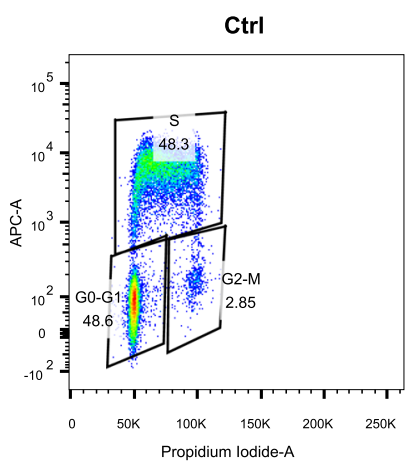

C

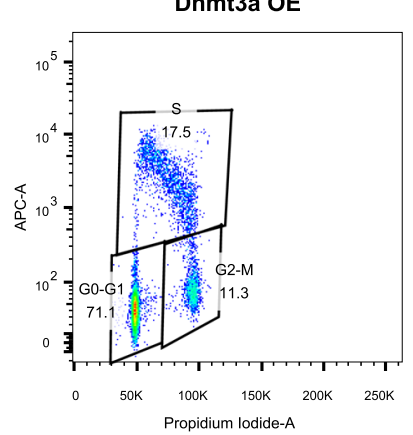

B

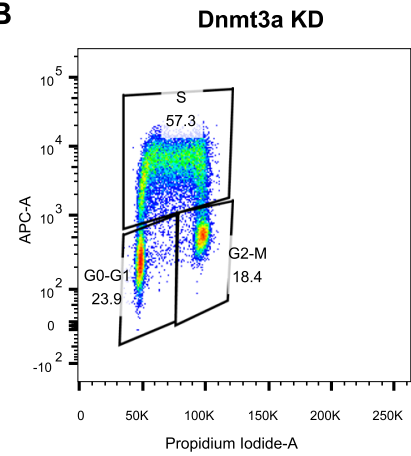

D

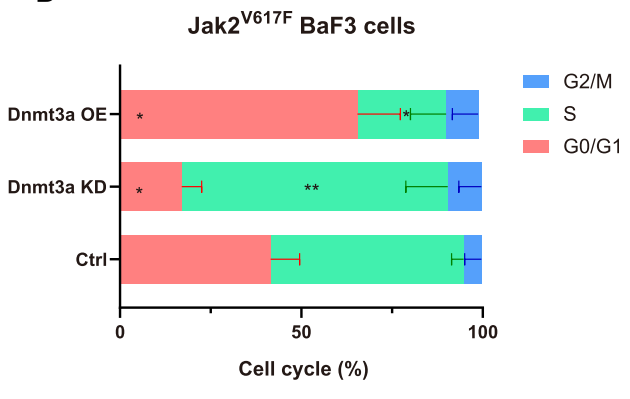

Fig. 6 Dnmt3a regulates the cell cycle of Jak2 ${ }^{\mathrm{V} 617 \mathrm{~F}} \mathrm{BaF3}$ cells by regulating Cdkn1a expression. A. Cell cycle distribution of Jak2 ${ }^{\mathrm{V} 617 \mathrm{~F}} \mathrm{BaF3}$ cells. B. Cell cycle distribution of Dnmt3a-knockdown Jak2 ${ }^{\mathrm{V} 617 \mathrm{~F}} \mathrm{BaF3}$ cells. C. Cell cycle distribution of Dnmt3a-overexpressing Jak2 ${ }^{\mathrm{V} 617 \mathrm{~F}} \mathrm{BaF3}$ cells. D. Cell cycle distribution statistics of each group (A-C) of Jak2 ${ }^{\mathrm{V} 617 \mathrm{~F}} \mathrm{BaF} 3$ cells

the expression level of Cdkn1a in several different groups of Jak2 ${ }^{\mathrm{V} 617 \mathrm{~F}}$ Baf3 cells, as shown in Fig. 8A (Supplementary Fig. 16). When incubated with LY2784544, the inhibitor of Stat5a, the expression of Dnmt3a was elevated, and the expression of Cdkn1a increased simultaneously.
Furthermore, when Dnmt3a was knocked down, the expression of Cdkn1a was correspondingly reduced. Besides, the expression level of Cdknla was observed to increase in Jak2 ${ }^{\mathrm{V} 617 \mathrm{~F}}$ BaF3 cells overexpressing Dnmt3a (Fig. 8B and Supplementary Fig. 17). Thus, we concluded that

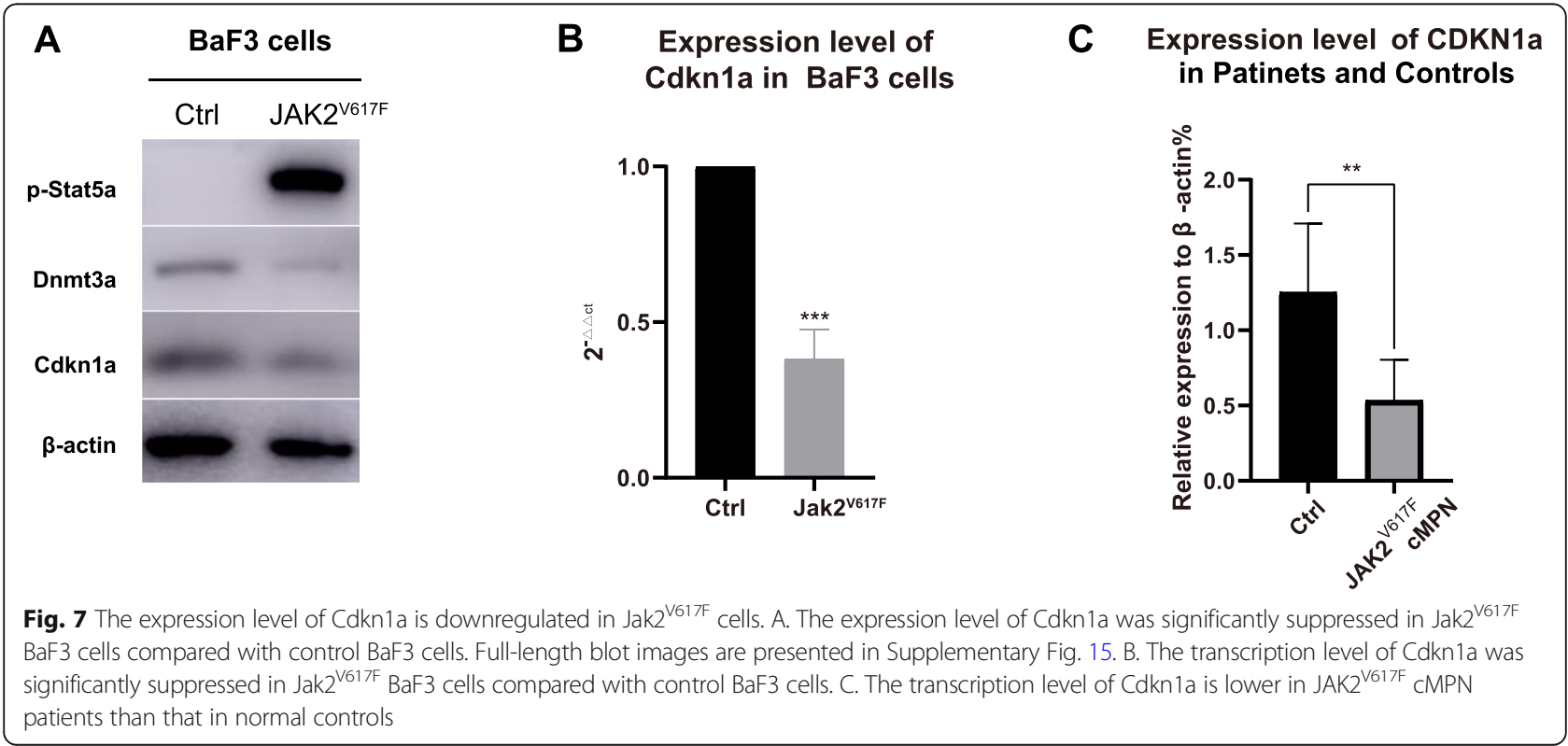


A

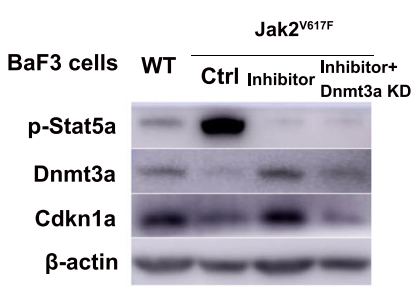

C

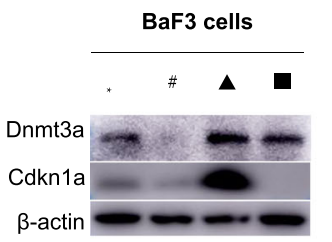

$*$ WT

\#: JAK2 $2^{\mathrm{V} 617 \mathrm{~F}}$

A : JAK2 $2^{\mathrm{V} 617 \mathrm{~F}}+\mathrm{Dnmt} 3 \mathrm{a}$ OE

- : JAK2 $2^{\mathrm{V} 17 \mathrm{~F}}+\mathrm{Dnmt} 3 \mathrm{a} \mathrm{OE}$ + Cdkn1a KD
B

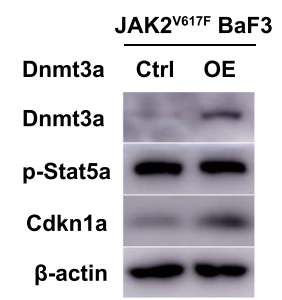

D

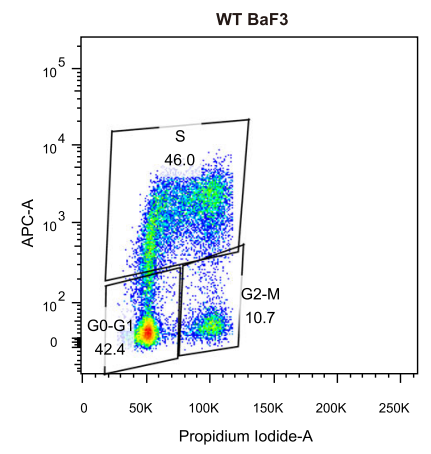

E

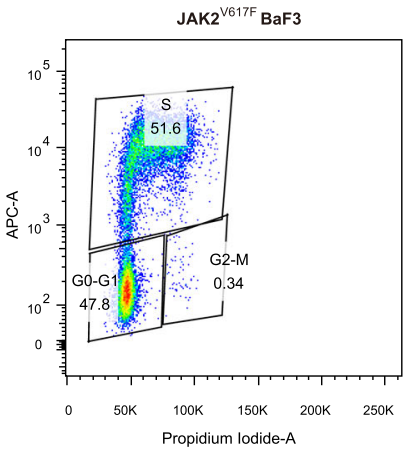

G

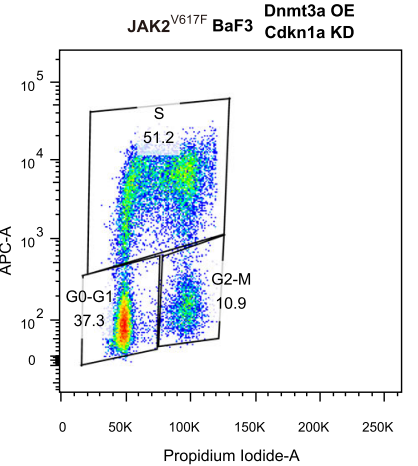

$\mathbf{F}$

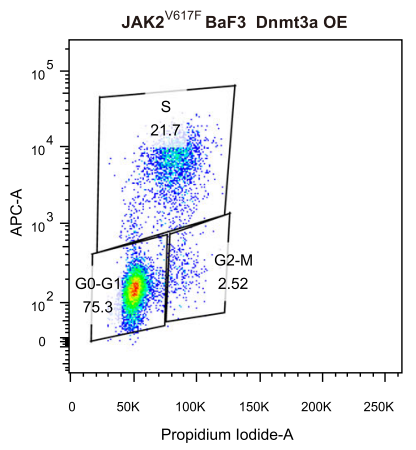

H

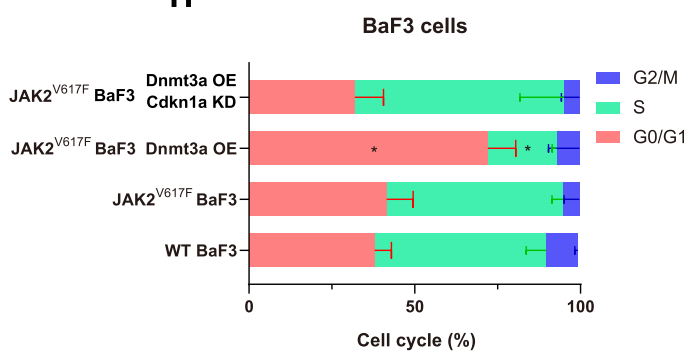

Fig. 8 Dnmt3a regulates the cell cycle of Jak2 ${ }^{\mathrm{V} 617 \mathrm{~F}}$ Baf3 cells through Cdkn1a. A \& B. Dnmt3a induced Cdkn1a expression in Jak2 ${ }^{\mathrm{V} 617 \mathrm{~F}}$ BaF3 cells. Full-length blot images are presented in Supplementary Fig. 16 and Supplementary Fig. 17. Inhibitor: LY2784544 incubation. C. Jak2 ${ }^{\text {V617F }}$ Baf3 cells with Dnmt3a overexpression and with both Dnmt3a overexpression and Cdknla knockdown were established. Full-length blot images are presented in Supplementany Fig. 18. D. Cell cycle distribution of wild-type BaF3 cells. E. Cell cycle distribution of Jak2 ${ }^{\mathrm{V} / 17 \mathrm{~F}}$ BaF3 cells. F. Cell cycle distribution of Jak2 ${ }^{\mathrm{V} 617 \mathrm{~F}}$ BaF3 cells with Dnmt3a overexpression. G. Cell cycle distribution of Jak2 ${ }^{\mathrm{V} 617 \mathrm{~F}}$ BaF3 cells with both Dnmt3a overexpression and Cdknla knockdown. H. Cell cycle distribution statistics of each group of Jak2 $2^{\mathrm{V} 17 \mathrm{~F}} \mathrm{BaF} 3$ cells 
Dnmt3a can positively regulates the expression of the Cdkn1a gene in Jak2 ${ }^{\text {V617F }}$ BaF3 cells.

We also established three types of stable cell lines to further study the relationship among Jak2 ${ }^{\mathrm{V} 617 \mathrm{~F}}$, Dnmt3a and Cdkn1a: the Jak2 ${ }^{\mathrm{V} 617 \mathrm{~F}} \mathrm{BaF} 3$ cell line $\left(J a k 2^{\mathrm{V} 617 \mathrm{~F}}\right)$, the Jak2 ${ }^{\text {V617F }}$ BaF3 with Dnmt3a overexpression (Jak2 ${ }^{\text {V617F }}+$ Dnmt3a OE) cell line, and the Jak2 ${ }^{\mathrm{V} 617 \mathrm{~F}} \mathrm{BaF} 3$ with both Dnmt3a OE and Cdkn1a knockdown (Jak2 ${ }^{\mathrm{V} 617 \mathrm{~F}}+$ Dnmt3a $\mathrm{OE}+\mathrm{Cdkn1a}$ KD) cell line (Fig. $8 \mathrm{C}$ and Supplementary Fig. 18). The cell cycle analysis was performed and the results were shown in Fig. 8D-Fig. 8G. The cell cycle distribution of wild-type BaF3 cells (WT) and Jak2 ${ }^{\mathrm{V} 617 \mathrm{~F}} \mathrm{BaF} 3$ cells (Jak2 ${ }^{\mathrm{V} 617 \mathrm{~F}}$ ) showed no significant differences in cell cycle (Fig. 8D and Fig. 8E). The Dnmt3a-overexpressing Jak2 ${ }^{\mathrm{V} 617 \mathrm{~F}} \mathrm{BaF} 3$ cells showed obvious cell cycle blockade in the G0/G1 phase (Fig. 8F) and after we knocked down Cdkn1a expression in Dnmt3a-overexpressing Jak2 ${ }^{\text {V617F }}$ BaF3 cells, the G0/G1 cell cycle blockade was eliminated and showed no significant difference compared with Jak2 ${ }^{\mathrm{V} 617 \mathrm{~F}}$ BaF3 cells (Fig. $8 \mathrm{G}$ and $\mathrm{H}$ ). The results indicated that Dnmt3a can cause the cell cycle blockade in Jak2 ${ }^{\mathrm{V} 617 \mathrm{~F}}$ cells and Dnmt3a carries out this function via Cdkn1arelated pathway.

In summary, all of the experiments above elucidated from different aspects that Dnmt3a suppresses the proliferation capacity of Jak2 ${ }^{\mathrm{V} 617 \mathrm{~F}}$ cells by mediating G0/G1 arrest via positive-regulating the Cdkn1a expression in Jak2 ${ }^{\text {V617F }}$ cells.

\section{Dnmt3a negatively regulates miR-17-5p and miR-17-5p represses Cdkn1a expression}

It has been reported that Dnmt3a suppresses the miR$17-5 p$ in mouse models [12] and there is a conserved site for miR-17-5p at the 3'UTR of mouse Cdkn1a with high context score (98) and 7 mer seed match (Table 3) according to TargetScanMouse database (http://www. targetscan.org /mmu_72/). Thus we suspect that miRNA may play a role in the regulation of Cdkn1a by Dnmt3a. To confirm the hypothesis, we detected the expression level of miR-17-5p in Jak2 ${ }^{\text {V617F }}$ BaF3 cells, control BaF3 cells, Jak2 ${ }^{\mathrm{V} 617 \mathrm{~F}} \mathrm{BaF} 3$ cells with Dnmt3a overexpression and Jak2 ${ }^{617 F}$ BaF3 cells with Dnmt3a knockdown. It was observed that the expression of miR-17-5p was higher in Jak2 ${ }^{\text {V617F }}$ BaF3 cells than in control BaF3 cells (Fig. 9A). The expression level of miR-17-5p in Jak $2^{\mathrm{V} 617 \mathrm{~F}} \mathrm{BaF} 3$ cells was also higher than the Jak2 ${ }^{\mathrm{V} 617 \mathrm{~F}} \mathrm{BaF} 3$ cells with Dnmt3a overexpression, but lower than that in Jak2 ${ }^{\mathrm{V} 617 \mathrm{~F}}$ BaF3 cells with Dnmt3a knockdown (Fig. 9B and C,

Table 3 miR-17-5p target sequences of Cdkn1a mRNA 3'-UTR

\begin{tabular}{ll}
\hline & Sequence \\
\hline miR-17-5p & 3'-GAUGGACGUGACAUUCGUGAAAC-5' \\
Cdkn1a 3'UTR & 5'-CCUCAGACCUGAAUAGCACUUUG-3' \\
\hline
\end{tabular}

Supplementary Fig. 19). These observation indicated that expression of miR-17-5p is negatively correlated with Dnmt3a, and Dnmt3a might negatively regulates the expression of miR-17-5p. The decreased expression of Dnmt3a was accompanied by the increased expression of miR-17-5p due to the reduced inhibition of Dnmt3a on miR-17-5p in Jak2 ${ }^{\mathrm{V} 617 \mathrm{~F}}$ BaF3 cells.

Then miR-17-5p mimic and inhibitor were transfected into Jak2 ${ }^{\mathrm{V} 617 \mathrm{~F}}$ BaF3 cells and the expression alteration were confirmed by RT-qPCR. In Jak $2^{\mathrm{V} 617 \mathrm{~F}} \mathrm{BaF} 3$ cells transfected with miR-17-5p mimic, the transcriptional and translational levels of Cdkn1a was decreased (Fig. 9D-F, Supplementary Fig. 19). Consistently, in Jak2 ${ }^{\mathrm{V} 617 \mathrm{~F}} \mathrm{BaF} 3$ cells transfected with miR-17-5p inhibitor, the transcriptional and translational levels of Cdkn1a was increased (Fig. 9D-F, Supplementary Fig. 19). These results indicated that Cdkn1a is a downstream target of miR-17-5p and inhibited by miR-17-5p in Jak2 ${ }^{\mathrm{V} 617 \mathrm{~F}}$ BaF3 cells.

In summary, as miR-17-5p inhibits the expression of Cdkn1a and Dnmt3a downregulats the expression of miR-17-5p in Jak2 ${ }^{\mathrm{V} 617 \mathrm{~F}} \mathrm{BaF} 3$ cells, the mechanism under which Cdkn1a expression is changed in Dnmt3a expression-altered cells might be Dnmt3a attenuate the inhibition of Cdkn1a mediated by miR-17-5p. Finally, the graphic abstract of the present study was shown in Fig. 9G.

\section{Discussion}

DNA methylation is an important epigenetic mechanism that interferes tumogenesis [13]. Mutations in the gene encoding DNMT3a were reported in patients with various hematological malignancies, pointing to DNMT3a as a critically important new tumor suppressor [14-16]. Our study found that abnormally activated Stat5a inhibits the transcription and translation of Dnmt3a by occupying the GAS motif of the promoter of Dnmt3a and downregulating the transcriptional activity of the promoter of Dnmt3a. Dnmt3a in Jak2 ${ }^{\text {V617F }}$ cells positively regulates the expression of Cdkn1a via miR-17-5p and significantly affects cell proliferation, mediating G0/G1 cell cycle arrest in Jak2 ${ }^{\mathrm{V} 617 \mathrm{~F}} \mathrm{BaF} 3$ cells. Therefore, we speculate that the axis of Stat5a/Dnmt3a/miR-17-5p/ Cdkn1a identified in this study in $\mathrm{JAK} 2^{\mathrm{V} 617 \mathrm{~F}}$-positive cells might play an important role in cMPNs and potentially provides a treatment target for cMPNs.

The somatic JAK $2^{\mathrm{V} 617 \mathrm{~F}}$ mutation is well known to play a crucial role in classical myeloproliferative neoplasms. $\mathrm{JAK} 2^{\mathrm{V} 617 \mathrm{~F}}$ mutation was reported to promote the pathogenesis and progression of hematological tumors by regulating downstream target genes. For example, expression of HIF- $1 \alpha$ was elevated in Jak $2^{\mathrm{V} 617 \mathrm{~F}}$-expressing $32 \mathrm{D}$ cells, and inhibition of the binding of HIF-1 to hypoxia response elements (HREs) with echinomycin impairs the growth and survival of Jak $2^{\mathrm{V} 617 \mathrm{~F}}$-positive 
A

$$
\begin{aligned}
& \text { Expression level } \\
& \text { of miR-17-5p }
\end{aligned}
$$

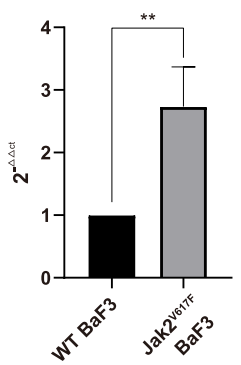

D

miR-17-5p in Jak2 ${ }^{\mathrm{V} 617 \mathrm{~F}}$ BaF3

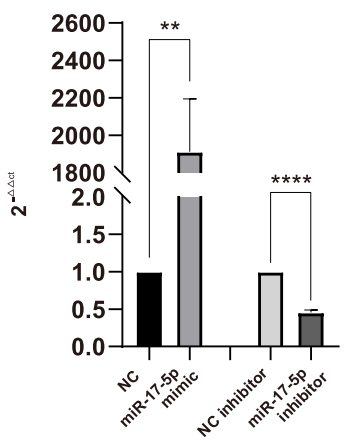

B

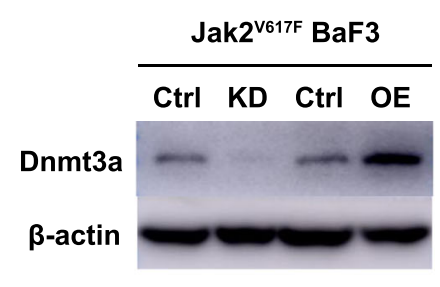

E

Expression level of
dkn1a in Jak2

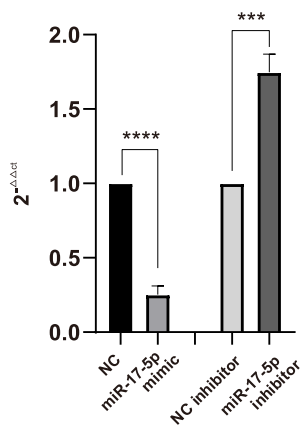

C

$$
\begin{aligned}
& \text { Expression level } \\
& \text { of miR-17-5p }
\end{aligned}
$$

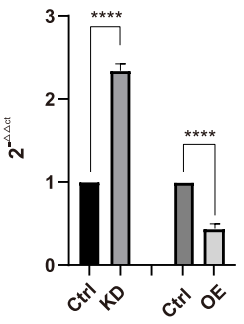

$\mathbf{F}$

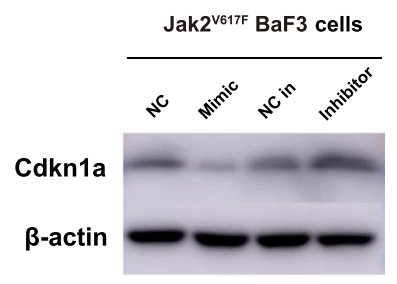

G

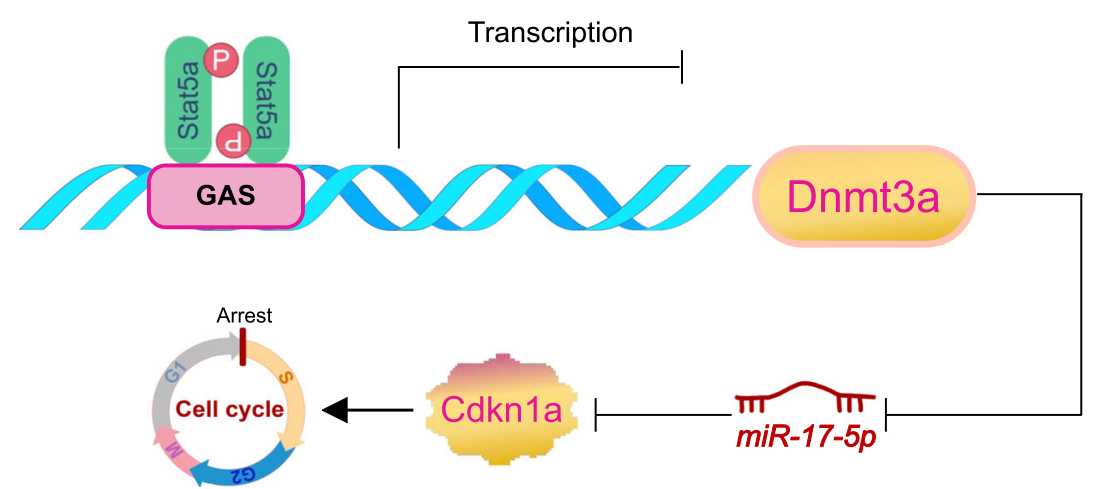

Fig. 9 Dnmt3a negatively regulates miR-17-5p and miR-17-5p represses Cdkn1a expression in Jak2 ${ }^{\mathrm{V} 617 \mathrm{~F}}$ BaF3 cells. A. The expression level of miR$17-5 p$ in Jak2 ${ }^{\mathrm{V} 617 \mathrm{~F}} \mathrm{BaF} 3$ cells and control BaF3 cells. B. The verification of the knockdown and overexpression effect of Dnmt3a in Jak2 ${ }^{\mathrm{V} 617 \mathrm{~F}} \mathrm{BaF3}$ cells. Full-length blot images are presented in Supplementary Fig.19. C. The expression level of miR-17-5p in Jak2 ${ }^{\text {V617F }}$ BaF3 cells with Dnmt3a knockdown and overexpression. D. The verification of the effect of transfection of miR-17-5p mimic and inhibitor in Jak2 ${ }^{\mathrm{V} 617 \mathrm{~F}} \mathrm{BaF} 3$ cells. E \& F. The transcription and expression of Cdkn1a in Jak2 ${ }^{\mathrm{V} 617 \mathrm{~F}} \mathrm{BaF3}$ cells transfected with miR-17-5p mimic or inhibitor. Full-length blot images are presented in Supplementary Fig.19. G. Graphic abstract of the present study

32D cells [17]. The JAK2 ${ }^{\mathrm{V} 617 \mathrm{~F}}$ mutation also enforced Mcl-1 transcription to sensitize myelodysplastic syndrome cell lines to apoptosis induced by a Bcl-xL/Bcl-2 inhibitor [18]. While the mutation of DNMT3a is known to play an important role in the pathogenesis of cMPN and a synergistic carcinogenic effect is known to exist for cMPNs driven by JAK2 ${ }^{\mathrm{V} 617 \mathrm{~F}}$ and DNMT3a deletion, how the Dnmt3a is regulated by Jak $2^{\mathrm{V} 617 \mathrm{~F}}$ mutation still needs research. Here, we found that in Jak2 ${ }^{\mathrm{V} 617 \mathrm{~F}} \mathrm{BaF} 3$ cells, the expression of Dnmt3a was inhibited compared with the wild-type BaF3. Further investigation of Stat5a inhibitor and Stat5a knockdown or overexpression found that the reduction in Dnmt3a in Jak2 ${ }^{\mathrm{V} 617 \mathrm{~F}} \mathrm{BaF} 3$ cells was mediated by abnormal activation of Stat5a. 
Subsequently, we overexpressed and knocked down Stat5a in wild-type BaF3 cells and found that as the expression of the Stat5a protein increased or decreased, the expression of Dnmt3a decreased or increased, respectively. Therefore, our research shows that the inhibition of Dnmt3a expression is mediated by abnormally activated Stat5a protein, indicating that Dnmt3a is a target gene of Stat5a in Jak2 ${ }^{\text {V617F }}$ BaF3 cells.

Signal transducer and activator of transcription (STAT) proteins reportedly bind to palindromic sites to regulate target gene expression $[19,20]$, and STAT5 transcription factors take part in the formation of DNAprotein complexes [21]. In the present study, dualluciferase reporter vector assays were performed to identify the promoter region of Dnmt3a. Incubation with a Stat5a inhibitor significantly induced the promoter activity of the Dnmt3a promoter, while overexpression and activation of Stat5a reduced the promoter activity of the Dnmt3a promoter. Furthermore, after GAS in the Dnmt3a promoter region was mutated, incubation with the Stat5a inhibitor did not influence the activity of the mutated promoter. ChIP assays of Stat5a on the Dnmt3a promoter further demonstrated that Stat5a binds to the promoter region of Dnmt3a. Taken together, these results represent an important and critical discovery of our study; that is, Stat5a inhibits Dnmt3a expression by directly occupying promoter region of Dnmt3a. As shown in Fig. 4, Stat5a also occupied the ChIP6 region and there is a GAS site (TTCCAGGAA) in ChIP6 region, but according to the results of Fig. $3 \mathrm{~B}$ and $3 \mathrm{C}$, neither transcription activity of P3 nor Region3 was altered after incubation of LY2784544, and ChIP6 is located at Region3. It's one of limitations of the study that the effect of mutation of GAS site at ChIP6 region was not examined and the reason why transcription activity of P3 nor Region3 was altered after incubation of LY2784544 was not explored. Our further study will follow up persistently.

DNMT3a belongs to a family of highly conserved DNA methyltransferases that catalyze 5-methylcytosine methylation and methylate DNA at unique sites as well as at repetitive elements [14]. It was reported that hematopoietic-specific Dnmt3a loss in mice leads to enhanced stem-cell self-renewal at the expense of differentiation and predisposes mice to the acquisition of cooperating proleukemogenic mutations in the expanded clone [22]. In our study, we found that knockdown of Dnmt3a in Jak2 ${ }^{\mathrm{V} 617 \mathrm{~F}} \mathrm{BaF} 3$ cells significantly inhibited cell proliferation and induced G0/G1 phase cell cycle arrest. Our results showed that Dnmt3a might mediate G0/G1 phase cell cycle arrest by positively regulating the $\mathrm{G} 1 / \mathrm{S}$ checkpoint marker Cdkn1a. It has been reported that compared with AML patients with FLT3 mutations alone, AML patients with mutations of both DNMT3A and FLT3 showed homeobox gene overexpression and enhancer hypomethylation, which resulted in a lower enrichment score of G2/M checkpoint genes [23]. Our study demonstrated that in JAK2 ${ }^{\text {V617F }}$ cMPNs, Dnmt3a positively regulates the expression of Cdkn1a, which induces G0/G1 cell cycle arrest, indicating that Dnmt3a also serves as a tumor suppressor in cMPNs by regulating the cell cycle through Cdkn1a, which in turn affects the proliferative capacity of Jak2 ${ }^{\mathrm{V} 617 \mathrm{~F}} \mathrm{BaF} 3$ cells. Although Dnmt3a is a de novo methyltransferase [24] and usually induces the downregulation of target genes [25], in some carcinomas, Dnmt3a and p53 are positively correlated and play an important role in disease progression [26, 27]. The p53-p21 axis arrested the cell cycle at G2/M and prompted partial EMT and fibrosis together with inflammation [28]. Our study found that Cdkn1a induced cell cycle arrest at G0/G1 in Jak2 ${ }^{\mathrm{V} 617 \mathrm{~F}} \mathrm{BaF} 3$ cells, which was regulated by the expression of Dnmt3a. Futhermore, we found that miR-17-5p inhibits the expression of Cdkn1a and Dnmt3a downregulats miR-17-5p in Jak2 ${ }^{\text {V617F }}$ BaF3 cells, thus the mechanism under which Cdkn1a expression is changed in Dnmt3a expressionaltered cells might be Dnmt3a attenuate the inhibition of Cdkn1a mediated by miR-17-5p. However, the direct regulation mechanism between Dnmt3a and miR-17-5p has not been explored, which is one of limitation of the study, will be followed up persistently in our future study. The deficiency of lack of in vivo validation will also be addressed in our future studies.

\section{Conclusions}

In conclusion, our research reveals that Dnmt3a is a downstream target of Stat5a, it is negatively regulated by the Stat5a through occupance of the promoter region of Dnmt3a, and that Dnmt3a induces cell cycle arrest at the G0/G1 phase in Jak2 ${ }^{\mathrm{V} 617 \mathrm{~F}}$ Baf3 cells through Cdkn1a, which is down-regulated by the miR-17-5p. Our discovery of the Stat5a/Dnmt3a/miR-17-5p/Cdkn1a axis existing in $\mathrm{JAK} 2^{\mathrm{V} 617 \mathrm{~F}}$ cells might shed new light on the pathogenesis of JAK2 $2^{\mathrm{V} 617 \mathrm{~F}}$-positive cMPNs and will inform new approaches to treatment.

\section{Abbreviations}

AML: Acute myeloid leukemia; Cdkn1a: Cyclin dependent kinase inhibitor 1a; CDS: Coding DNA Sequence; ChIP: Chromatin immunoprecipitation; cMPNs: Classical myeloproliferative neoplasms; DMEM: Dulbecco's modified Eagle's medium; DMSO: Dimethyl sulfoxide; Dnmt3a: DNA methyltransferase 3 alpha; ET: Essential thrombocythemia; FLT3: Fms Related Receptor Tyrosine Kinase 3; GAS: Gamma-activated sequence motif; GFP: Green fluorescent protein; HIF-1a: Hypoxia inducible factor 1 subunit alpha;

HSPC: Hematopoietic stem/progenitor cells; JAK2: Janus Kinase 2; Mcl1: MCL1 Apoptosis Regulator, BCL2 Family Member; PMF: Primary myelofibrosis; Puro: Puromycin; PV: Polycythemia vera; RPMI: Roswell Park Memorial Institute; shRNA: short hairpin RNA; Stat5a: Signal transducer and activator of transcription 5 a 


\section{Supplementary Information}

The online version contains supplementary material available at https://doi. org/10.1186/s12885-021-08915-0.

Additional file 1: Table S1. Clinical characteristics of 12 samples (six JAK2V617F-positive cMPNs patients and six normal controls), from which bone marrow mononuclear cells were isolated

Additional file 2: Table S2. Primer sequences of different promoter regions of Dnmt3a (-2860 bp to +140 bp)

Additional file 3: Fig. S1. Uncropped images of Fig. 1A

Additional file 4: Fig. S2. Uncropped images of Fig. 1C

Additional file 5: Fig. S3. Uncropped images of Fig. 1D

Additional file 6: Fig. S4. Uncropped images of Fig. $1 \mathrm{E}$

Additional file 7: Fig. S5. Uncropped images of Fig. 2A

Additional file 8: Fig. S6. Uncropped images of Fig. $2 B$

Additional file 9: Fig. S7. Uncropped images of Fig. 2C

Additional file 10: Fig. S8. Uncropped images of Fig. 2D

Additional file 11: Fig. S9. Uncropped images of Fig. $2 E$

Additional file 12: Fig. S10. Uncropped images of Fig. $2 F$

Additional file 13: Fig. S11. Uncropped images of Fig. $2 \mathrm{G}$

Additional file 14: Fig. S12. Uncropped images of Fig. $2 \mathrm{H}$

Additional file 15: Fig. S13. Uncropped images of Fig. $3 E$

Additional file 16: Fig. S14. Uncropped images of Fig. 4B

Additional file 17: Fig. S15. Uncropped images of Fig. 7A

Additional file 18: Fig. S16. Uncropped images of Fig. 8A

Additional file 19: Fig. S17. Uncropped images of Fig. 8B

Additional file 20: Fig. S18. Uncropped images of Fig. $8 C$

Additional file 21: Fig. S19. Uncropped images of Fig. $9 B$ and $F$

\section{Acknowledgements}

We would like to thank Dr. Zhuoyi FAN, Dr. Fangce WANG and Mr. Lei LUO for their technical assistance and advice.

\section{Authors' contributions}

JZ and CG conceived the study, conducted the experiments and wrote the original draft of manuscript. HW, BL and LZ provided assistance in the source of experimental equipment and materials. AL and JF reviewed and edited the manuscript. JF is the recipient of fundings and supervise the present project. All authors read and approved the final manuscript.

\section{Funding}

This present work was supported by the National Natural Science Foundation of China (Grant No. 81372497), and Shanghai Pujiang Talents Plan (Grant No. 18PJD044). The funding body did not contribute to any of the following: design of the study, data collection, data analysis, interpretation of data, writing the manuscript or decision to publish.

\section{Availability of data and materials}

The data used and/or analysed during the current study are available from the corresponding author on reasonable request.

\section{Declarations}

\section{Ethics approval and consent to participate}

The use of clinical samples in our study was according to the Declaration of Helsinki and was approved by the Ethics Committee of Tongji hospital of Tongji University on Feb. 2021 (Number: 2021-KYSB-177). Written informed consent was obtained from each participant.

\section{Consent for publication}

Not applicable.

\section{Competing interests}

The authors declare that they have no competing interests.

\section{Author details}

${ }^{1}$ Tongji University School of Medicine, Shanghai 200092, China. ${ }^{2}$ Department of Gastroenterology, Tongji Hospital of Tongji University, Shanghai 200065, China. ${ }^{3}$ Department of Hematology, Tongji Hospital of Tongji University, Tongji University School of Medicine, No.389 Xincun Road, Putuo District, Shanghai 200065, China.

Received: 23 July 2021 Accepted: 26 October 2021

Published online: 13 November 2021

\section{References}

1. Ozono Y, Shide K, Kameda T, Kamiunten A, Tahira Y, Sekine M, et al. Neoplastic fibrocytes play an essential role in bone marrow fibrosis in Jak2V617F-induced primary myelofibrosis mice. Leukemia. 2021;35(2):45467. https://doi.org/10.1038/s41375-020-0880-3.

2. Lundberg P, Karow A, Nienhold R, Looser R, Hao-Shen H, Nissen I, et al. Clonal evolution and clinical correlates of somatic mutations in myeloproliferative neoplasms. Blood. 2014;123(14):2220-8. https://doi.org/1 0.1182/blood-2013-11-537167.

3. Vainchenker W, Kralovics R. Genetic basis and molecular pathophysiology of classical myeloproliferative neoplasms. Blood. 2017;129(6):667-79. https:// doi.org/10.1182/blood-2016-10-695940.

4. Ginno PA, Gaidatzis D, Feldmann A, Hoerner L, Imanci D, Burger L, et al. A genome-scale map of DNA methylation turnover identifies site-specific dependencies of DNMT and TET activity. Nat Commun. 2020;11(1):2680. https://doi.org/10.1038/s41467-020-16354-x.

5. Bullinger $L$, Döhner K, Döhner $H$. Genomics of acute myeloid leukemia diagnosis and pathways. J Clin Oncol. 2017;35(9):934-46. https://doi.org/1 0.1200/jco.2016.71.2208.

6. Jacquelin S, Straube J, Cooper L, Vu T, Song A, Bywater M, et al. Jak2V617F and Dnmt3a loss cooperate to induce myelofibrosis through activated enhancer-driven inflammation. Blood. 2018;132(26):2707-21. https://doi. org/10.1182/blood-2018-04-846220.

7. Takeuchi A, Nishioka C, Ikezoe T, Yang J, Yokoyama A. STAT5A regulates DNMT3A in CD34(+)/CD38(-) AML cells. Leuk Res. 2015;39(8):897-905. https://doi.org/10.1016/j.leukres.2015.05.006.

8. Arber DA, Orazi A, Hasserjian R, Thiele J, Borowitz MJ, Le Beau MM, et al. The 2016 revision to the World Health Organization classification of myeloid neoplasms and acute leukemia. Blood. 2016;127(20):2391-405. https://doi. org/10.1182/blood-2016-03-643544.

9. Livak KJ, Schmittgen TD. Analysis of relative gene expression data using real-time quantitative PCR and the $2(-$ Delta Delta C(T)) method. Methods. 2001;25(4):402-8. https://doi.org/10.1006/meth.2001.1262.

10. Soldaini E, John S, Moro S, Bollenbacher J, Schindler U, Leonard WJ. DNA binding site selection of dimeric and tetrameric Stat5 proteins reveals a large repertoire of divergent tetrameric Stat5a binding sites. Mol Cell Biol. 2000;20(1):389-401. https://doi.org/10.1128/mcb.20.1.389-401.2000.

11. Dutto I, Tillhon M, Cazzalini O, Stivala LA, Prosperi E. Biology of the cell cycle inhibitor p21(CDKN1A): molecular mechanisms and relevance in chemical toxicology. Arch Toxicol. 2015;89(2):155-78. https://doi.org/10.1007/s00204014-1430-4.

12. Yang ZG, Awan FM, Du WW, Zeng Y, Lyu J, Wu D, et al. The circular RNA interacts with STAT3, increasing its nuclear translocation and wound repair by modulating Dnmt3a and miR-17 function. Mol Ther. 2017;25(9):2062-74. https://doi.org/10.1016/j.ymthe.2017.05.022.

13. Flavahan WA, Gaskell E, Bernstein BE. Epigenetic plasticity and the hallmarks of cancer. Science. 2017;357(6348). https://doi.org/10.1126/science.aal2380.

14. Yang $L$, Rau R, Goodell MA. DNMT3A in haematological malignancies. Nat Rev Cancer. 2015;15(3):152-65. https://doi.org/10.1038/nrc3895.

15. Venugopal K, Feng Y, Shabashvili D, Guryanova OA. Alterations to DNMT3A in hematologic malignancies. Cancer Res. 2021;81(2):254-63. https://doi. org/10.1158/0008-5472.can-20-3033.

16. Chaudry SF, Chevassut TJ. Epigenetic Guardian: a review of the DNA methyltransferase DNMT3A in acute myeloid Leukaemia and clonal Haematopoiesis. Biomed Res Int. 2017;2017:1-13. https://doi.org/10.1155/2 017/5473197.

17. Baumeister J, Chatain N, Hubrich A, Maié T, Costa IG, Denecke B, et al. Hypoxia-inducible factor 1 (HIF-1) is a new therapeutic target in JAK2V617F- 
positive myeloproliferative neoplasms. Leukemia. 2020;34(4):1062-74. https://doi.org/10.1038/s41375-019-0629-z

18. Bartalucci N, Tozzi L, Bogani C, Martinelli S, Rotunno G, Villeval JL, et al. Cotargeting the PI3K/mTOR and JAK2 signalling pathways produces synergistic activity against myeloproliferative neoplasms. J Cell Mol Med. 2013;17(11): 1385-96. https://doi.org/10.1111/jcmm.12162.

19. Rivas ML, Cobreros L, Zeidler MP, Hombría JC. Plasticity of Drosophila Stat DNA binding shows an evolutionary basis for Stat transcription factor preferences. EMBO Rep. 2008;9(11):1114-20. https://doi.org/10.1038/embor.2 008.170

20. Hayashi M, Futawaka K, Koyama R, Fan Y, Matsushita M, Hirao A, et al. Effects of growth hormone on uncoupling protein 1 in white adipose tissues in obese mice. Growth Hormon IGF Res. 2017;37:31-9. https://doi. org/10.1016/j.ghir.2017.10.006.

21. Flisikowski K, Szymanowska M, Zwierzchowski L. The DNA-binding capacity of genetic variants of the bovine STAT5A transcription factor. Cell Mol Biol Lett. 2003;8(3):831-40.

22. Jeong M, Park HJ, Celik H, Ostrander EL, Reyes JM, Guzman A, et al. Loss of Dnmt3a immortalizes hematopoietic stem cells in vivo. Cell Rep. 2018;23(1): 1-10. https://doi.org/10.1016/j.celrep.2018.03.025.

23. Yang L, Rodriguez B, Mayle A, Park HJ, Lin X, Luo M, et al. DNMT3A loss drives enhancer Hypomethylation in FLT3-ITD-associated Leukemias. Cancer Cell. 2016;29(6):922-34. https://doi.org/10.1016/j.ccell.2016.05.003.

24. Zhang ZM, Lu R, Wang P, Yu Y, Chen D, Gao L, et al. Structural basis for DNMT3A-mediated de novo DNA methylation. Nature. 2018;554(7692):38791. https://doi.org/10.1038/nature25477.

25. Mao Q, Wu S, Gu X, Du S, Mo K, Sun L, et al. DNMT3a-triggered downregulation of $K(2 p) 1.1$ gene in primary sensory neurons contributes to paclitaxel-induced neuropathic pain. Int J Cancer. 2019;145(8):2122-34. https://doi.org/10.1002/ijc.32155.

26. Kataoka I, Funata S, Nagahama K, Isogaya K, Takeuchi H, Abe N, et al. DNMT3A overexpression is associated with aggressive behavior and enteroblastic differentiation of gastric adenocarcinoma. Ann Diagn Pathol. 2020;44:151456. https://doi.org/10.1016/j.anndiagpath.2019.151456.

27. Haney SL, Upchurch GM, Opavska J, Klinkebiel D, Hlady RA, Roy S, et al. Dnmt3a is a Haploinsufficient tumor suppressor in CD8+ peripheral T cell lymphoma. PLoS Genet. 2016;12(9):e1006334. https://doi.org/10.1371/journa l.pgen.1006334.

28. Qi R, Wang J, Jiang $Y$, Qiu Y, Xu M, Rong R, et al. Snai1-induced partial epithelial-mesenchymal transition orchestrates p53-p21-mediated G2/M arrest in the progression of renal fibrosis via NF-KB-mediated inflammation. Cell Death Dis. 2021;12(1):44. https://doi.org/10.1038/s41419-020-03322-y.

\section{Publisher's Note}

Springer Nature remains neutral with regard to jurisdictional claims in published maps and institutional affiliations.

Ready to submit your research? Choose BMC and benefit from:

- fast, convenient online submission

- thorough peer review by experienced researchers in your field

- rapid publication on acceptance

- support for research data, including large and complex data types

- gold Open Access which fosters wider collaboration and increased citations

- maximum visibility for your research: over $100 \mathrm{M}$ website views per year

At BMC, research is always in progress.

Learn more biomedcentral.com/submissions 